\title{
Index Theory: The Law, Promise and Failure of Financial Indices
}

\author{
Gabriel Rauterberg and Andrew Verstein $\dagger$
}

Financial indices, like the $S \& P 500$ or the Consumer Price Index, have become a ubiquitous feature of our financial markets. One index, the London InterBank Offered Rate ("Libor"), may be the world's most important number, an interest rate benchmark upon which hundreds of trillions of dollars depend. Yet, almost every day new revelations emerge that Libor was tampered with during the height of the financial crisis by one or many of the world's most prominent banks, with billions of dollars potentially misappropriated. This index disruption has attracted tremendous interest from regulators, private litigants, and market observers. Despite their importance, however, financial indices are poorly understood, and almost completely unstudied. In this Article, we explain why and how people use financial indices as well as how they are created. We show human discretion and value judgment to be essential ingredients in even the most "objective" indices. We then develop a taxonomy of financial indices, illustrating how the risks indices can pose, and the solutions applicable to those risks, are intimately related to the motivation that drives the index's creation. We show that the manipulation of indices is unsurprising given the precarious state of intellectual property rights in indices. While many call for prosecuting or regulating the Libor banks, our novel solution is to strengthen property rights for those who create financial indices.

Introduction

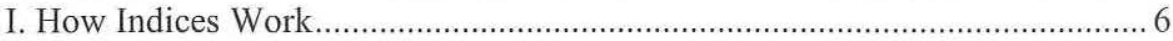

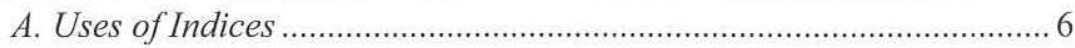

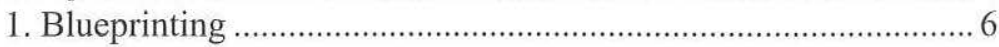

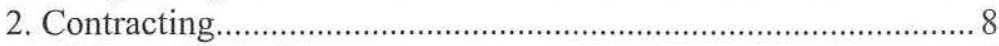

i. Long-Term Contracts......................................................... 9

$\dagger \quad$ Gabriel Rauterberg is an attorney in private practice and received his J.D. from Yale Law School. Andrew Verstein is an Associate Research Scholar in Law, Lecturer in Law, and John R. Raben/Sullivan \& Cromwell Executive Director of the Center for the Study of Corporate Law at Yale Law School. The authors are grateful for the extensive comments of Ian Ayres, Quinn Curtis, Marc Flandreau, Daniel Gorfine, Michael Graetz, David Grewal, Alvin Klevorick, Bruce Kobayashi, Jake Linford, Noah Messing, John Morley, Larry Ribstein, Roberta Romano, Peter Siegelman, Natalya Shnitser, Norman Silber, Lynn Wang, Louis E. Wolcher, and the participants in the Georgetown University Law School roundtable on Soft Law and the Global Financial System, including Christopher Brunner, Anna Gelpern, Adam Levitin, Heidi Schooner, Robert B. Thompson, and David Zaring. 
ii. Derivative Contracts .

3. Price Information ............................................................... 13

B. Methodology \& The Myth of Objectivity ............................................... 15

1. Goal-Oriented Methodologies................................................... 18

2. Accuracy: One Virtue Among Many ........................................... 21

3. Data: No Mathematics Without Judgment.......................................2 24

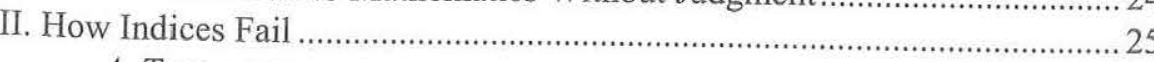

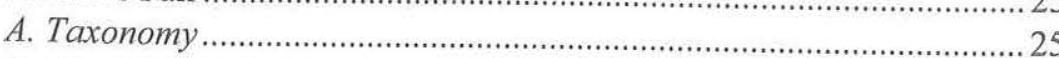

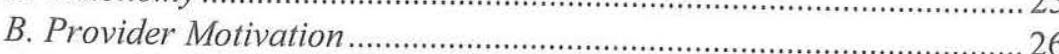

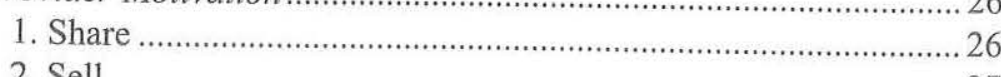

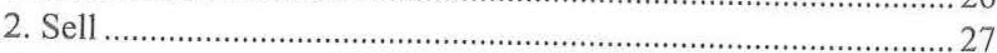

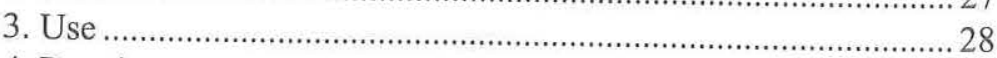

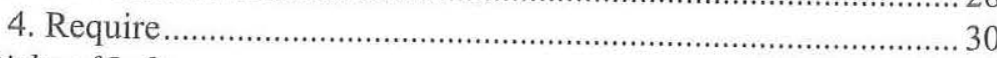

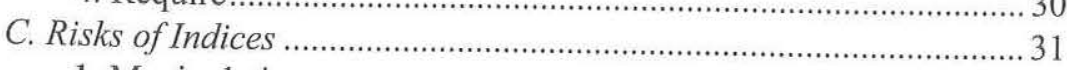

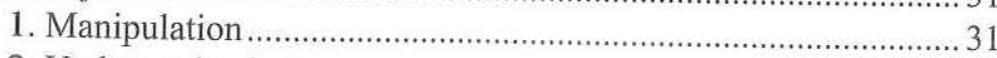

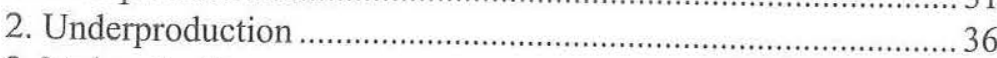

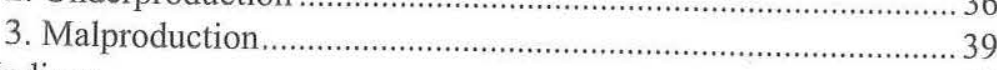

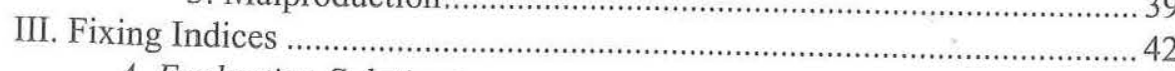

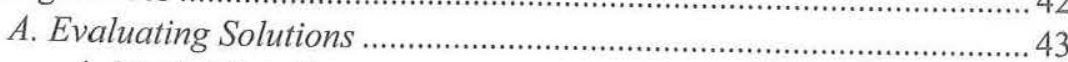

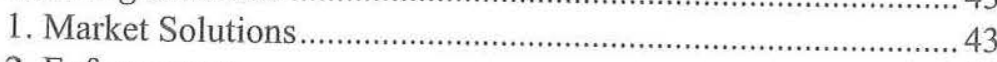

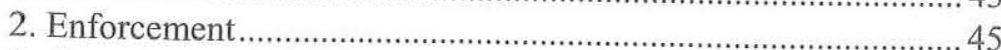

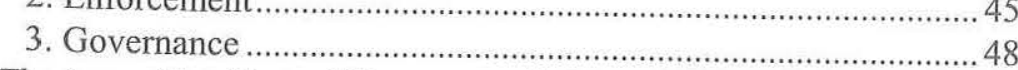

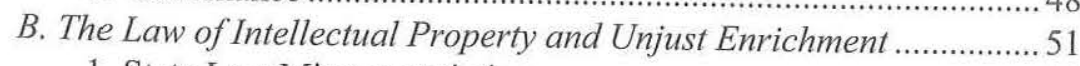

1. State Law Misappropriation......................................................51

i. Indices as "Hot News" ......................................................... 52

ii. Indices as Securities....................................................... 55

iii. Consequences of Declining Property Protetion..................... 56

2. Restoring Property ..............................................................5 56

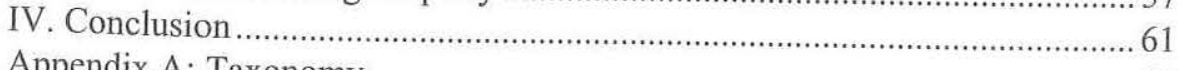

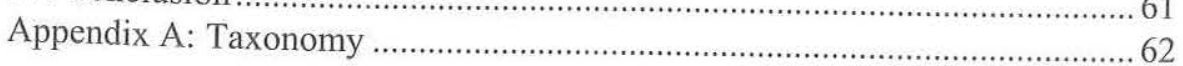

\section{Introduction}

Libor has been called "the world's most important number." It is "the dominant global benchmark for interest rates"2 and represents the cost of

1. LIBOR: The World's Most Important Number, MONEYWEeK, Oct. 10, 2008, http://www. moneyweek.com/personal-finance/libor-the-worlds-most-important-number-13816; see also Donald Mackenzie, What's in a Number?, LONDON REV. BOOKS, Sept. 27, 2008, at 11 (describing Libor's ST. J., Apr. 16, 2008, at A1, http://onliner Fog: Bankers Cast Doubt on Key Rate Amid Crisis, WALL $\$ 500$ trillion in contracts are indexed to Libor). 2. MacKenzie, suma not 1, at $11 ; 0$.

Doubt on Key Rate, WALL ST. J., May 29, 2008, at \& Mark Whitehouse, Study Casts SB121200703762027135.html (explaining that Libor "plays a vital A1, http://online.wsj.com/article money for hundreds of millions of people and hundreds of trillions of dollars, from high finance to homeowners. Over $\$ 360$ trillion is indexed to Libor ${ }^{3}$ - the London InterBank Offered Rate ${ }^{4}$ - or about $\$ 50,000$ per human being. Libor is "the language of the large capital markets," dominating the interest-rate swap markets, ${ }^{6}$ syndicated loans, ${ }^{7}$ and powerfully influencing residential and commercial mortgages. ${ }^{8}$ And in the worst hours of the financial crisis, some of Libor's makers set out to manipulate it.

In recent months, dozens of bank employees have lost their jobs for attempting to manipulate Libor, ${ }^{9}$ including top executives at major investment banks. ${ }^{10}$ Most prominently, Barclays Plc recently disclosed a litany of abuses by its traders and paid $\$ 450$ million to settle some of US and UK regulators' allegations. ${ }^{11}$ Japanese regulators have imposed penalties for attempted manipulation of the Tibor, Tokyo's Libor equivalent, ${ }^{12}$ and several banks have admitted their traders' involvement in a rate-fixing scheme to authorities. ${ }^{13}$ All at once, economists, ${ }^{14}$ journalists, ${ }^{15}$ plaintiffs' lawyers, ${ }^{16}$ and regulators ${ }^{17}$ have turned to ask whether Libor was successfully manipulated and how.

3. Global Financial Stability Report: Financial Stress and Deleveraging - Macrofinancial Implications and Policy, INT'L MONETARY FUND, at xv (Oct. 2008), http://www.imf.org/external pubs/ft/gfsr/2008/02/pdf/text.pdf; Dennis Kuo, David Skeie \& James Vickery, A Comparison of Libor to Other Measures of Bank Borrowing Costs 1 (June 2012) (unpublished manuscript), http://www.newyorkfed.org/research/economists/vickery/LiborKSV_staff_webpage.pdf.

4. The Basics, BBA LIBOR, http://www.bbalibor.com/bbalibor-explained/the-basics (last visited Feb. 27, 2012)

5. Mike Carsella, Libor: Immensely Important-Little Understood, SECURED LENDER, July/August 2009, at 47, 48, http://www.thesecuredlender-digital.com/thesecuredlender/20090708/ $? \mathrm{pg}=49$.

6. Kuo et al., supra note 3

7. Xanthe Lok, Libor and Market Disruption: The Future of Libor, 23 BUTTERWORTHS J. INT’L BANKING \& FIN. L. 421, 421 (2008).

8. Justin T. Wong, Libor Left in Limbo; A Call for More Reform, 13 N.C. BANKING INST. J. 365,365 (2009) (reporting that Libor is the reference rate for $\$ 900$ billion in subprime mortgages); Carrick Mollenkamp et al., Libor's Rise May Sock Many Borrowers, WALL ST. J., Apr. 19, 2008, at B1, http://online.wsj.com/article/SB120856108868827857.html; Kuo et al., supra note 3.

9. Richard Pullin, Traders Fired, Suspended Over LIBOR Probe: FT, REUTERS (Feb. 8, 2012, 9:32 PM), http://www.reuters.com/article/2012/02/09/us-investigation-interbank-lending idUSTRE81807L20120209; UBS Fires Traders and Managers Over Libor-Report, WALL ST. J. (Aug. 5, 2012, 11:32 AM), http://online.wsj.com/article/BT-CO-20120805-700657.htm

10. Sara Schaefer Muñoz \& Max Colchester, Top Officials at Barclays Resign Over Rate Scandal, WALL ST. J. (July 4, 2012, 8:22 AM), http://online.wsj.con/

article/SB1. Steve Slater, Barclays Sets Out Defense on Libor Fixing, REUTERS (July 3, 2012, 6:2
11. PM), http://www.reuters.com/article/2012/07/03/us-barclays-defence-idUSBRE8621C020120703.

12. Atsuko Fukase, Update: Japan's Financial Regulators Sanction Citi Japan for $3 \mathrm{rd}$ Time in Seven Years, WALL ST. J. (Dec. 16, 2011, 6:34 AM), http://online.wsj.com/article/BT-CO-20111216-

13. Jean Eaglesham, Paul Vieira \& David Enrich, Traders Manipulated Key Rate, Bank Says, WALL ST. J., Feb. 17, 2012, at Cl, http://online.wsj.com/article/SB100014240529702

14. See, e.g., Connan Snider \& Thomas Youle, Does the LIBOR Reflect Banks' Borrowing Costs? (Apr. 2, 2010) (unpublished manuscript), http://ssrn.com/abstract=1569603. 
These revelations are surprising to many who assume that Libor is based on observable market data and is incapable of manipulation. Few realize that Libor is published by a consortium of Libor's biggest users, the British Bankers' Association. It uses banks' proprietary data and is highly discretionary due to its reliance on subjective judgment. In the end, Libor is calculated and set every day by the judgment of one man, John Ewan, a financial-services professional in his mid-thirties. ${ }^{18}$ Despite its importance, its susceptibility to influence, and allegations of its manipulation, Libor remains essentially unregulated.

The effects of index manipulation could be vast. Back-of-the-envelope estimates suggest that fraudulent interest rates could have generated billions of dollars in illicit profits for the scheme's perpetrators ${ }^{19}$ and transferred more than a trillion dollars from the scheme's victims. ${ }^{20}$ One study found that if the 6-month Libor hovered $1.75 \%$ higher than historical averages, as it did in early 2008 , then the average subprime borrower would pay an additional $\$ 100$ per month per $\$ 100,000$ of home equity. ${ }^{21}$ Thus a modest manipulation upward in Libor could easily extract $\$ 1000$ to $\$ 2000$ per year from a typical subprime borrower. Regressive by any standard, this would increase mortgage defaults at a time when they already pose systemic risk concerns. The story is little better if Libor ends up too low: "A lower Libor induces a lower mortgage rate, makes it easier to buy homes, substituting homes away for other goods. This artificially inflates the prices of homes . . . hav[ing] the potential to lead to bubbles and meltdowns of the type we are currently experiencing." 22 Most importantly, regardless of who wins or loses in a particular manipulation, faulty Libor quotes undermine the integrity and efficiency of the world's borrowing markets.

On the one hand, Libor is unique. Its importance is arguably greater than any other product, firm, or even industry, and its manipulation is front-page news. On the other hand, Libor is just one of many financial indices, all of

15. See, e.g., Gillian Tett, Bank Lending Probe Lights Up Dark Financial Corners, FIN. TIMES, Feb. 9, 2012, at 20, http://www.ft.com/int $/ \mathrm{cms} / \mathrm{s} / 0 / 3 \mathrm{~d} 4447 \mathrm{~b} 98-533 \mathrm{e}-1$ lel-aafd00144feabdc0.html.

16. See In re Libor-Based Fin. Instrum 17. Carrick Mollenkamp, Exclusive: U.S. Conducting Criminal Libor Probe, ReUTERS (Feb. 29, 2012, 11:24 AM), http://www.reuters.com/article/2012/02/29/us-libor-probe-

18. Interview with John Ewan, Managing Director, BBA Libor (June 15, 2011).

19. Tom Osborn, Is Libor in Its Death Throes?, FiN. NEws (Oct. 31, 2011), http://www efinancianews.com/story/2011-10-31/libor-deth-throes.

20. Libor Penalty, FIN. TIMES LEXICON (Feb. 10, 2012, $8: 02 \quad$ PM), http://www.ft.com/int //cms//3/3/01 aeca7a-53f2-1 lel-bacb-00144feabdc0.html.

21. Mark Schweitzer \& Guhan Venkatu, Adjustable-Rate Mortgages and the Libor Surprise,

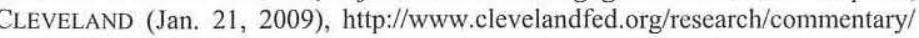

22. Rosa M. Abrantes-Metz, Sofia B. Villas-Boas \& George Judge, Tracking the Libor Rate, 18 APPLIED ECON. LETTERS 893, 897-99 (2011). which are little understood, but many of which have great importance. The S\&P 500 is the leading indicator of the state of the U.S. economy and the stock market's daily returns, with well over $\$ 1$ trillion of investments tied to it alone. Almost one-third of all federal outlays rise with CPI, the Consumer Price Index, as do federal marginal tax rates. ${ }^{23}$ Everywhere we rely on indices to aggregate information, guide our investments, and settle our contracts.

In light of their importance, the scholarly neglect of financial indices is remarkable. As one observer has remarked: "Only a handful of economists, and no other academics, have ever looked in any detail at Libor." ${ }^{24}$ Critical thinking about other indices fares no better. Academics and regulators have largely ignored the indispensable role indices play in markets, failing to articulate why financial indices have grown so quickly in importance, how they function, and the risks they face.

This Article attempts to answer the tough questions about Libor: given the impartial character we associate with indices, how is it even possible to manipulate Libor? Given the risks of manipulation, why did users trust it (and why do they continue to trust it)? Why would a bank risk its credibility through manipulation? What can we do to prevent potential manipulation in the future?

But these are equally questions about all indices. Indices are the indispensable and invisible infrastructure of modern finance, and this Article aims to provide the theoretical tools necessary to illuminate them.

Part I explains how indices work. Section A shows how parties use indices as blueprints for investments, as referents for contracts, and as sources of information. Section B argues that these benefits are rooted in methodologies driven far more by human discretion than many might have expected. In explaining the inner life of indexing, we refute a myth of objectivity that prevents any realistic understanding of indices. Regulators and scholars alike ignore the ineradicable subjectivity that is part of the index production process As a result, they fixate on solutions that eliminate, rather than manage, human involvement in index creation.

We then move in Part II to our primary ambition: a theory of financial indices. In Section A, we develop a taxonomy to categorize and illuminate the world of financial indices. Section B discusses the different motivations for

23. Michael J. Boskin et al., Toward a More Accurate Measure of the Cost of Living: Final Report to the Senate Finance Committee From the Advisory Commission to Study the Consumer Price Index (Dec. 4, 1996) [hereinafter Boskin Report], reprinted in GETTING PRICES RIGHT: THE DEBATE OVER THE CONSUMER PRICE INDEX 5, 13 (Dean Baker ed., 1998); see also Alex M. Parker, Debt Ceiling Deal Could Mean Social Security Cuts, U.S. News \& WorLD REr., June 28, 2011, at ("Changing the CPI would affect Social Security benefits and retirement payments for federa employees, as well as income taxes, but could be billed by lawmakers as a technical adjustment, not tax hike or benefit cut."). See generally Bart Hobijn \& David Lagakos, Social Security and the Consumer Price Index for the Elderly, CURRENT ISSuES ECON. \& FIN. (Fed. Reserve Bank of N.Y.), May 2003, at 1 (discussing relationship between CPI and social security payments).

24. MacKenzie, supra note 1, at 11 . 
index production and argues that these motivations are the defining feature of each type of index. In Section C, we discuss the different risks indices face and the ways in which indices can fail. Finally, in Section D, we survey potential solutions to index problems. We show throughout that the model and taxonomy we have developed for analyzing indices predicts the risks that specific indices will face and the solutions that are best suited to those risks. There is no "best" type of index, no single solution that works well across index types, and no solution without tradeoffs.

Though there are no easy answers, we show that the most commonly discussed solutions to the Libor disruption-market-based contracting, litigation-based enforcement, and government control over the process-are insufficient. We make an alternative proposal. We offer the first scholarly examination of the law-intellectual property law-governing indices as a business, and argue that it is intellectual property law that offers the most promising approach to preventing many forms of index dysfunction. For decades, financial index providers had secure property rights, which provided ncentives for them to produce adequate quality and quantity. Recent judicial decisions have severely limited index providers' rights, pressuring many indices to accept more conflicted and compromised business models. We propose restoring and rationalizing index property rights.

\section{How Indices Work}

\section{A. Uses of Indices}

There are three basic uses for indices: they are used as (1) blueprints to guide investment, (2) contract referents, and (3) information sources. These uses explain why there are now over $\$ 1.6$ trillion in assets invested in vehicles that track indices, ${ }^{25}$ and hundreds of trillions of dollars contractually based on an index referent. ${ }^{26}$

\section{Blueprinting}

One of the most important uses of indices is as investment blueprints. In the financial architecture of the early twentieth century, investment managers served as both architects and general contractors for actively managed funds. They would conceive of the investment strategy and then execute trades to implement it. But it will sometimes be cheaper for many general contractors to

25. Knowledge@Wharton, If Index Funds Perform Better, Why Are Actively Managed Funds More Popular?, WHARTON SCH., UNIV. OF PENN. (Feb. 2, 2011), http://knowledge.wharton.upenn.edu/ le.cfm?articleid $=2702$.

26. Kuo et al., supra note 3 , at 1 . hire a single architect than for each to hire its own ${ }^{27}$ It is even possible for many contractors to work from the same blueprint, capitalizing the cost of drafting the plan across many identical homes. Indices are blueprints for investment strategies.

An index fund follows clear instructions regarding which assets to buy in order to track the returns of a financial index. The S\&P 500's input list and methodology is used as an investment plan (buy these 500 stocks in such-andsuch proportions, and then rebalance the portfolio as the index changes) that many funds follow. In this way, Standard \& Poor's serves by proxy as fund manager for the many funds that track the S\&P 500 .

The use of financial indices as blueprints provides three important benefits for investors. First, it allows investors to profit from economies of scale. Individual needs are often similar enough that a single blueprint will satisfy many different people, who can share the cost of its production. Rather than hiring a fund manager, a fund can subscribe to a financial index and replicate its composition and returns. Indexed investing is often cheaper than individua management, ${ }^{28}$ which can significantly increase an investor's overall return. ${ }^{29}$

Second, the use of indices as blueprints can lower governance and monitoring costs. An investor in an actively managed fund may find it difficult to determine the quality of her investment manager. Returns may be determined by forces other than the manager's behavior, and expensive bonding and monitoring may be required to guarantee trust. ${ }^{30}$ However, it is easy for investors to verify the quality of an index fund manager. Such funds publish their expense ratios and how closely their strategy tracked the index return. These two variables are easy to understand and compare. The return from most S\&P 500 exchange traded funds (ETFs) should be identical, subject to fees and tracking error, allowing competition to discipline managers. ${ }^{31}$

Finally, index-guided investment lets retail investors take advantage of two of the most important financial insights of the late twentieth century: the Efficient Markets Hypothesis, which posits that market prices reflect all

27. For a discussion of the shared management of an entire fund family, see John Morley, The Separation of Investments and Management (Mar. 1, 2012) (unpublished manuscript), http://www.law.yale.edu/documents/pdf/cbl/Morley_The_Separation_of_Investments_and_Managemen pdf.

28. Vanguard Expense Ratios, VANGUARD GrouP (2009), https://advisors.vanguard.com/iwe/pdf/FASHERC.pdf (noting that Vanguard expenses to investors are a mere $0.2 \%$ of assets)

${ }^{29}$. Mutual Fund Fees and Expenses, U.S. SEC. \& EXCHANGE COMm'N, http://www.sec.gov/answers/mffees.htm (last modified Aug. 8, 2007). $\$ 10,000$ invested at $10 \%$ return for 20 years yields about $\$ 60,000$ if annual fees are $0.5 \%$, which is typical of an index fund. A managed fund charging $1.5 \%$ would leave the investor with less than $\$ 50,000$

30. See generally Michael C. Jensen \& William H. Meckling, Theory of the Firm: Managerial Behavior, Agency Costs and Ownership Structure, 3 J. FiN. EcoN, 305, 308-09 (1976) (describing gency costs in terms of monitoring, bonding and residual loss)

31. Even funds that do not track the index use it as a basis for comparison. Many funds compare themselves to the S\&P 500 as a useful touchstone for describing risk and return. 
available financial information, ${ }^{32}$ and Modern Portfolio Theory, which posits that diversified portfolios can achieve similar returns at less risk than undiversified portfolios - or superior returns with equal risk. ${ }^{33}$

At the intersection of these two theories is the index fund, which is an investment strategy based on investing in a diversified portfolio of passively managed assets. Asset managers rely on an index to provide the recipe for diversification, saving costs along the way. ${ }^{34}$

Indeed, a broad consensus has emerged that passive, indexed investing outperforms actively managed funds. ${ }^{35}$ When costs are included, index funds surpass actively managed investment strategies, year after year. ${ }^{36}$ As Burton Malkiel has put it, there is "[a] remarkably large body of evidence suggesting that professional investment managers are not able to outperform index funds that simply buy and hold the broad stock market portfolio" and that "[t]hroughout the past decade about three-quarters of actively managed funds have failed to beat the index." ${ }^{, 37}$

\section{Contracting}

While funds are concerned with index inputs as blueprints, contracts are concerned with index outputs as reference terms. The use of indices as contract terms allows parties to (i) achieve more efficient coordination, especially in long-term contracts, and (ii) construct more sophisticated and precise investing instruments and derivatives.

\section{i. Long-Term Contracts}

Long term contracts involve significant risks of opportunism. After the parties agree to terms, the market price may change, tempting one party to escape the contract in order to buy or sell on the open market. Amid this uncertainty, many long-term contracts require specific investments in equipment and processes. ${ }^{38}$ Fear of opportunism and breach discourage transaction-specific investments that increase the gains from trade.

For parties who wish to make a long-term agreement, there are many contractual solutions to these problems. For example, the parties could set fixed prices now, complete with a schedule of future changes (say, a 5\% increase per year). Another solution is a cost-plus contract, in which the seller bills the buyer for the production cost plus some fixed margin, which protects the seller against price swings and eliminates their temptation to breach opportunistically. Alternatively, the parties could select some single price number to act as a referent in their contracts, such as the prime rate of a well-known bank. ${ }^{39}$ Hopefully, that rate would move in keeping with their target price.

Financial indices often outperform each of these options. Negotiating a price schedule encourages both parties to engage in potentially wasteful price research so that they can propose a price schedule that is likely to benefit them. ${ }^{40}$ Despite such research, the parties are likely to guess incorrectly about future prices and find themselves with an inefficient contract. ${ }^{41}$

Cost-plus contracts suffer from high monitoring and moral hazard costs. A contract written in reference to the seller's costs may be subject to manipulation, provide poor incentives to control costs, and require expensive monitoring efforts. ${ }^{42}$ Cost-plus contracts also require the seller to make their costs known, spawning confidentiality concerns that the seller may prefer not to risk. $^{43}$

38. Nick van der Beek, Long-Term Contracts and Relational Contracts, in 6 ENCYCLOPEDIA F LAW AND ECON vics 281, 283 (Gerit De Gest ed 2d ed. 2011).

39. E.g., FDIC v. Blanton, 918 F.2d 524, 532 (5th Cir. 1990) ("[T]he contract specifies a prematurity rate equal to FNB-Midland Prime plus one percent .....'

40. VICTOR GoLDBERG, Framing CONTRACT LAW 328 (2007). See also Alexander J. Triantis George G. Triantis, Timing Problems in Contract Breach Decisions, 41 J.L. \& Econ. 163, 196 (1998) 41. Paul L. Joskow, Price Adjustments in Long-Term Contracts: The Case of Coal, 31 J.L. \& ECON. 47, 52 (1988). "If the probability of wasteful behavior increases as the divergence between contract price and the opportunity cost of the aggrieved party widens, price adjustment rules which narrow the gap become increasingly atractive. " GOLDBEG, supra note 40, at 329. See also Keth J. Most-Favored-Nation Clauses in Natural Gas Contracts, 37 J.L. \& ECON. 297,303 (1994). "The payof from indexing" Victor Goldberg states, "is from the reduction in the divergence between the contract price and the market price." GOLDBERG, supra note 40, at 329. To be sure, if the market price drops below the seller's costs, a market price index may tempt her to breach. But that is an efficient breach and should not cause concern.

42. Id. at 329-30, Penn. 1980) (ALCOA)).

36. BURTON MALKIEL, A RANDOM WALK DOWN WALL StREET (2003); Malkiel, The Efficien Market Hypothesis, supra note 33, at 77; William F. Sharpe, The Arithmetic of Active Management, FIN. .Feb. 1991, at 7

37. Malkiel, The Efficient Market Hypothesis, supra note 33, at 77-78. 
As for individual referents, they may vary in value idiosyncratically. By contrast, indices' diversified character reduces volatility. ${ }^{44}$ Volatility matters because the power to breach a contract can be considered an implicit, or embedded, option in that contract. ${ }^{45}$ As volatility is reduced, the exercise of the option becomes less profitable ${ }^{46}$ and breach becomes less likely. ${ }^{47}$

Effective contracting is about getting the best incentive bang for the contracting buck. ${ }^{48}$ In addition to effectively maximizing parties' incentives to perform, indices also allow parties to minimize the cost of negotiation by avoiding contractual questions that cost more to answer than they provide in benefits.

Some contracts are notoriously costly to negotiate. Mutual distrust, collective bargaining constraints, and wage stickiness can make labor and employment negotiations costly. ${ }^{49}$ Perhaps for this reason, unions were the earliest advocates of the use of consumer price indices as a reference point for wage terms in contracts. ${ }^{50}$ A mutually amenable index may rein in acrimonious discussions without requiring parties to resolve every outcome. ${ }^{51}$

Scholars have long understood that contracts are often left incomplete in rational reliance on subsequent judicial interpretation. ${ }^{52}$ Financial indices

44. Id. at 328 ,

45. Paul G. Mahoney, Contract Remedies and Options Pricing, 24 J. LEG. StUd. 139 (1995) (using option theory to explain the common law's preference for money damages rather than specific performance); Robert E. Scott \& George G. Triantis, Embedded Options and the Case Against Compensation in Contract Law, 104 CoLUM. L. REV. 1428, 1429 (2004) ("Rather than conceiving of damages as compensation, the right to breach and pay damages is better understood as a valuable option
sold by the promisee to the promisor."); Triantis \& Triantis, supra note 40 , at 201 (arguing that sold by the promisee to the promisor."); Triantis \& Triantis, supra note 40 , at 201 (arguing that expectation damages encourage inch
of plaintiff's own lost breach).

46. IAN Ayres, Optional LAW: THE STRUCTURE OF Legal ENTITLEMENTS 7, 44-66 (2005); JOHN C. HULL, FUNDAMENTALS OF FUTURES AND OPTIONS MARKETS 279-80 (5th ed. 2005); George S. Geis, An Embedded Options Theory of Indefinite Contracts, 90 MINN. L. REV. 1664, 1700 (2006).

47. Note, however, that basis risk can be increased if an inappropriate index is chosen or if the index provider changes its methodology. See Andrew Verstein, Interim Contracting (or Ex Tempore Contracting) (Aug. 6, 2012) (unpublished manuscript), http://ssrn.com/abstract=2125169.

48. Robert E. Scott \& George G. Triantis, Anticipating Litigation in Contract Design, 115 YALE L.J. 814, 817 (2006)

49. See generally ARTHUR M. OKUn, PRICES AND QUANTITIES: A MACROECONOMIC ANALYSIS (1981) (elaborating theory of wage stickiness).

50. See generally THOMAS A. STAPLEFORD, THE COST OF LIVING IN AMERICA 256 (2009) (describing the rise of the CPI in collective bargaining agreements). Irving Fisher insisted that his employees accept weekly wage modifications, subject to a wholesale price index established by the Index Number Institute. Robert W. Dimand, Irving Fisher and Index Bonds, 13 J. ECON. PERSP. 224 225 (1999). His employees' resistance to this program, particularly when it caused nominal wages to (1997), One wonders, however, whether resistance was duson." IRVING FISHER, THE MONEY ILLUSION conflicts of interest: the Index Number Institute operated out of Fisher's house. See Dimand, supra, at 225

51. Richard Posner describes deliberate ambiguity, another tool for avoiding a protracted negotiation, as "a form of compromise like 'agreeing to disagree."' Richard A. Posner, The Law and Economics of Contract Interpretation, 83 TEX. L. REV. 1581, 1583 (2005)

52. Scott \& Triantis, supra note 48 , at 845 provide an entirely new way to draft a less-than-fully-specified contract: the contracting parties agree to let the index provider decide the price..$^{53}$ That way the parties need not specify ex ante every day's price, but also they need not wait for ex post adjudication to know the price. When it is costly for contractors to decide, and it is costly for courts to decide, a financial index can decide, providing a type of "live" certainty as to obligations.

In addition to lowering total contracting and adjudication costs, this arrangement allows the parties to benefit from the index provider's expertise in pricing. ${ }^{54}$ For example, the parties in Eastern Air Lines v. Gulf Oil had set their oil supply contract to follow the Platts oil price index. ${ }^{55}$ Their contract did not specify what should happen if oil price controls were relaxed for some, but not all, of the relevant oil. It was probably rational for their contract not to resolve that peculiar issue ex ante. Yet, the parties might not have trusted a court to understand the commercial factors involved with resolving this issue. By contrast, Platts was well positioned to interpret how this market change affected the contract price. The index provider had detailed market data. It likely knew how other customers were affected by the recent market changes and it could use that information to make a methodological choice that jointly maximized all customers' contracts. The parties in Gulf Oil did not fully specify their price schedule for every contingency, but neither did they leave it to a judge; they left it to Platts.

\section{ii. Derivative Contracts}

Indices also enable cheaper forms of traditional investing and new forms of investable assets by facilitating financial derivative contracts. Many derivative contracts use a financial index number as the settlement value that determines who owes whom. For example, an S\&P 500 future contract pays an investor the value of the S\&P 500 on any given day.

Retail investors can use these contracts to achieve broad market exposure and diversification. ${ }^{56}$ Sophisticated investors can use index-based derivatives to implement increasingly nuanced investment strategies. Suppose an investor feels certain that Exxon will outperform the market but is unsure of how the market will do. With index options, she can make an investment that reflects this view by buying Exxon stock and shorting S\&P 500 futures. The net cost of the transaction could be zero and yet yield the exposure she desires.

53. See Verstein, supra note 47.

54. Id.

55. Eastern Air Lines, Inc. v. Gulf Oil Corp., 415 F. Supp. 429, 433 (S.D. Fla. 1975) (“The indicator selected by the parties was 'he average of the posted prices for West Texas sour crude, 30.0The posting of crude prices under the contract 'shall be as listed for these companies in Platts Oilgram The porvic Crude Oil Supplement. '”')

56. IAN AYRES \& BARRY NALEBUfF, LIFECYCLE INVESTING (2010). 
Financial indices also enable derivatives through which parties can hedge against the market's most daunting risks. Interest-rate derivatives were born out of increasing interest volatility, which created a risk that a bank's costs of funds would rise after having made a loan. Banks would have preferred to make variable-rate loans linking their revenue stream to the same forces shaping their liabilities, but borrowers strongly preferred the certainty of a fixed-rate loan. It might have seemed that either the bank or its borrower must bear the risk of interest rate fluctuation.

Index-linked derivatives allowed a third option: the bank could lend at a floating rate and the borrower could swap the floating rate obligation to some third party in exchange for a fixed obligation. Through this sort of triangular borrowing, the risk can be shifted to a party with an appetite for it. These kinds of transactions are now ubiquitous. An ISDA survey of derivative end-users found that $80 \%$ of responding companies used interest rate swaps to manage interest rate risks. ${ }^{57}$ The City of Baltimore, for example, has "hundreds of millions of dollars" in interest rate derivatives linked to Libor. ${ }^{58}$ Interest-rate swaps are the largest financial derivative by far, and Libor is the referent used in most of those contracts. ${ }^{59}$

Indices have also enabled investors to invest in specific kinds of assets that previously did not exist. For example the creation of the S\&P 500 index allowed the creation of the VIX, a volatility index. The VIX, published by the Chicago Board Options Exchange (CBOE), is a measure of the implied volatility of the S\&P $500{ }^{60}$ The VIX increases when stock prices are unstable and decreases when returns are most predictable. VIX contracts allow investors to take a position on volatility itself. It has been enormously popular as a result; VIX contracts are among the most traded on the CBOE. ${ }^{61}$ Changing one's volatility exposure is now as simple a matter as buying stock in Apple - it can be accomplished in seconds with an online trading account. The future of indices portends only greater asset creation and accessibility. ${ }^{62}$

57. ISDA End-User Survey: Interest Rate Swaps, INT'L SwAPS \& DeRIVATIVES ASS'N, INC, 2 Oct. 2010), http://www.isda.org/media/pdf/End-User-Survey-IRS-only.pdf.

58. See In re Libor, No. 1:11-md-02262, 2011 WL 5980198, at *2 (S.D.N.Y. Nov. 29, 2011),

59. Libor is also a settlement value in CME Eurodollar Futures Contracts, among the most liquid exchange traded derivatives.

60. Introduction to VIX Options and Futures, CHICAGO BD. OPTIONS EX., http://www Intocist (last visited Oct. 10, 2012)

61. Brendan Conway, Investing in Fear Is Big Business, WALL. ST. J., Nov. 29, 2010, at C1, http://online.wsj.com/aticle/SB10001424052748703785704575642643319238142.html.

62. See, e.g., Bhakti Mirchandani \& Alexandra Connell, 27 J.L. \& CoM. 209 (2009) (calling for a microfinance investment index in order to improve hedging and provide cheaper access to the industry)
3. Price Information

Finally, financial indices convey information, increasing price transparency and improving markets. Indices are powerful primarily because they solve collective action problems implicit in price discovery. First, price research is sometimes susceptible to the tragedy of the commons. ${ }^{63}$ Traders in a commodity are ex ante rational to investigate its price in other markets, as well as the likely future price. These research costs can become duplicative and wasteful as parties jockey for an informational edge at their counterparty's expense ${ }^{64}$ Indices can discourage excessive price research by allowing parties to share the research and its costs. By selling the fruit of its price research, index providers like Platts can act as designated investigators, bringing information to the market at a lower cost for all.

Indices also ingeniously solve the collective action problem of too little information production. Every trader has private information about commodity prices. They may know something about local supply levels, about the most recent price at which they transacted, or even their own willingness to buy or sell. Because this information ultimately bears on the commodity price, it is valuable. $^{65}$ Though each market participant enjoys free-riding on the information disclosure of other participants, none has an incentive to disclose her own.

Indices obtain private information by offering the prospect of liquidity and diversification to induce traders to share it, acting as a platform for information trading. ${ }^{66}$ For example, the ABX index, which tracks the value of mortgagebacked securities, has served as the settlement price for certain financial derivatives since $2006 .{ }^{67}$ Such derivatives allowed investors to place synthetic bets on the US subprime market and provided a payoff for expressing contrarian views (when right). These bets would affect the public price of the derivatives, allowing others to see which way the wind is blowing. ${ }^{68}$

63. See Garrett Hardin, The Tragedy of the Commons, 162 SCIENCE 1243 (1968)

64. This is akin to the racing problem often described in reference to homesteading and fishing. Louis Kaplow \& Steven Shavell, Economic Analysis and the Law, in 3 HANDBOOK OF PUBLIC ECONOMICS 1690 (Alan J. Auerbach \& Martin Feldstein eds., 2002).

65. Cf. J. Harold Mulherin, Jeffry M. Netter \& James A. Overdahl, Prices Are Property: The Organization of Financial Exchanges from a Transaction Cost Perspective, 34 J. L. \& ECON. 2 (1991) (analyzing history of information control and freeriding around exchanges); Pete Locke, Natural Gas Price Transparency and Liquidity 2-3 (Oct. 2006) (unpublished manuscript), http://www.ngsa.org/ assets/Docs/Natural_\%20Gas_Market_Transparency_October\%202006_Finall.pdf (discussing "free er" problem in trading.

66. Exchanges perform this function as well, but many assets, such as mortgage-backed securities, do not trade on exchanges.

67. Press Release, Markit Group, CDS Indexco and Markit Launch Synthetic ABS Index (Jan. 17, 2006), http://www.markit.com/en/media-centre/press-releases/detail.page?dcr=/markit/PressRelease/

68. Cf. Douglas J. LuCAS et al., Developments in Collateralized Debt Obligations: NEW PRODUCTS AND INSIGHTS 97 (2007) (describing importance of ABX index to information). 
Prior to the advent of the ABX, positions in subprime were expressed by negotiating bespoke derivatives with an investment bank. Gary Gorton identifies the "pivotal role" of the ABX, which by 2007, became "the focal point of the crisis," and contributed directly to the end of the real estate bubble. $^{69}$ By increasing transparency for market pricing, the ABX made clear that a large number of hedge funds were taking a bearish view of the subprime mortgage market. The pricing of a trade-sensitive index immediately incorporates and reflects trade information and by doing so, brings a level of liquidity and transparency to a market. ${ }^{70}$ Once traders had incentives to express their negative views about these assets through the public medium of the index's prices, their opinions became the market's common knowledge.

Improved and accessible pricing increases the efficiency of markets. Index prices may narrow trading spreads and lower barriers to entry. ${ }^{71}$ At the margin, some investors who have been deterred by high search costs may now be able to join the market, benefiting personally and improving liquidity for others. This increases liquidity for all participants, and so the value of the traded assets. $^{72}$

Information can also concentrate trading so as to generate important network effects. ${ }^{73}$ Network effects are a form of economy of scale, in which widespread adoption increases the total surplus. ${ }^{74}$ Indices can help to establish the index subject as the preferred contract or asset for traders, further increasing its liquidity, ${ }^{75}$ and generating secondary research data and derivative products. ${ }^{76}$ Traders and investors flock to the S\&P 500 index in part because of benefits described above- low costs, diversification, and trusted judgmentbut also because others have flocked to it.

69. Gary Gorton, The Subprime Panic, 15 EUR. FIN. MGMT. 10, 31 (2009).

70. Cf. LUCAS ET AL., supra note 68.

71. See Independent Price Assessment Data Helps Iron Ore Newcomer, Bahia Mineração, Mine for Competitive Intelligence, PLATTS (Oct. 2010), https://www.platts.com/IM.Platts.Content/ InsightAnalysis/IndustrySolutionPapers/BahiaMineracao CaseHistory.pdf.

72. J. Huston McCulloch, An Estimate of the Liquidity Premium, 83 J. PoL. ECON. 95 (1975); Perry Mehrling \& Daniel H. Neilson, A New Measure of Liquidity Premium (Jan. 31, 2008) (unpublished manuscript), http://www.peri.umass.edu/fileadmin/pdf/conference_papers/d_arista/ liquidity_darista.PDF.

73. There is a vast literature on networks and standards. See, e.g., JEAN TIROLE, THE THEORY OF INDUSTRIAL ORGANIZATIONS (1988); Joseph Farrell \& Garth Saloner, Standardization, Compatibility, and Innovation, 16 RAND J. ECON 70 (1985); Michael L. Katz \& Carl Shapiro, Network Externalities, Competition, and Compatiability, 75 AM. ECON. REV. 424 (1985).

74. Stan J. Liebowitz \& Stephen E. Margolis, WinNERS, Losers \& Microsoft 67 (2001) ("What most distinguishes networks from other instances of increasing returns is the benefits of increased size come from the demand side, the willingness of consumers to pay, and not the supply side, or the costs associated with production.")

75. João Garcia \& Serge Goossens, THe ART OF CRedit Derivatives: Demystifying THE BLACK SWAN $\$ 18.2 .1$, at 150 (2010) ("Liquidity comes from the ... use of the index as a mechanism for pricing discovery and portfolio management of bespoke portfolios.").

$$
\text { 76. See supra Part I.A. }
$$

\section{B. Methodology \& The Myth of Objectivity}

We must clear some brushwork before indices can be properly understood. The primary obstacle to such an understanding is a myth of objectivity, which characterizes indices as near-Platonic mathematical constructs that exist largely outside of human intervention and creativity. Yet, financial index production is a fundamentally discretionary and subjective activity. Recognizing the inherent discretion in financial index formation, we can seek solutions that improve the exercise of human discretion, rather than purge it.

Despite the ubiquity of judgment, most commentators accept this myth of objectivity, and its persistence obscures understanding of indices' promise and failure. ${ }^{77}$ According to this view, indices are either themselves objective facts or else factual statements about the world. For example, that the S\&P 500 is above 1000 is an observable, objective truth and one that does not rely on human judgment or interpretation. An index number is an observable truth, like the temperature. ${ }^{78}$ To the degree human choice is involved, there is only one proper choice for those humans: correctly convey the fact as it is

The myth of objectivity is common nowadays. Victor Goldberg, for example, has stated, "Indexing has the advantage of being mechanical and generally nonmanipulable."79 But the myth has a long history. Irving Fisher, the godfather of indexing, consistently speaks as though a given dataset can only be fairly represented by a single, objectively correct index number:

If we look at prices as starting at any time from the same point, they seem to scatter o disperse like the fragments prices. This average is the "index number."

Fisher suggests that there is only one true index number summarizing the data, and a functioning index should state it accurately. Within such a system, ambiguity of construction methodology cannot be justified. As one industry publication put it:

The methodology [of a good index] should be rules based and transparent. For instance,

77. On the social construction of the objectivity ideal, see THEODORE M. PORTER, TRUST IN NUMBERS: THE PURSUIT OF OBJECTIVITY IN SCIENCE AND PUBLIC LIFE (1995).

78. And yet, the temperature, too, has attracted attention as a subjective, social fact. See ALBerT CAMUS, NOTEBOOKS 1935-1942, at 98 (Philip Thody tr., 1963) ("The temperature . . . is something too fleeting to be established in mathematical concepts. Here, observations are arbitrary slices 79. GOLDBERG, supra note 40 , at 329.
7.

80. IRVING FISHER, THE MAKING OF INDEX Numbers 2-3 (3d ed. 1927); see also id. at 10 ("It should be the 'just compromise' among conflicting elements, the 'fair average,' the 'golden mean."'). 
primary exchanges. The methodology is based on pre-published rules and is transparent, i.e.,
there is no ambiguity as to what makes a stock eligible to be included in the index.

As no proper index permits the sort of ambiguities that might require judgment to interpret, there can be no justification for human intervention, which would constitute overriding the mechanical rules.

Such pre-arranged rules are possible because the goal is clearaccuracy - and the means consist of whatever good statistical techniques will deliver it. Fisher states that " $[\mathrm{t}]$ he fundamental purpose of an index number is that it shall fairly represent ... the many diverging ratios from which it is calculated. ${ }^{82}$ On this view, human discretion and creativity is anathema, and index providers should let the data do the talking. Index creation is a descriptive enterprise, not a normative one.

If this myth of objectivity were true, Libor would stand out as an aberration and the source of Libor's problems would be clear: it broke all the rules.

Libor is the average of the self-reported rates at which sixteen major commercial banks are offered large unsecured loans. ${ }^{83}$ Libor is managed by the British Bankers' Association (BBA) ${ }^{84}$ a trade association of UK banks, which controls the composition of the panel and the Libor calculation methodology. ${ }^{85}$ The Libor exists for ten different currencies and for 15 different maturities, varying from overnight to twelve months. ${ }^{86}$

Just before 11 a.m. each business day, a trader from each of the contributor banks sends Thomson Reuters his answer to the following question: at what rate could you borrow funds, were you to do so by asking for and then accepting inter-bank offers in a reasonable market size just prior to $11 \mathrm{am} ?^{87}$

This question leaves much to interpretation: how much is "a reasonable market size," for example? The bank treasurer has broad discretion about how to interpret and answer many such questions, and need not keep her

81. Francis Gupta, Indexes or Benchmarks:What's the Difference?, J. INDEXES, Nov./Dec. 2005, http://www.indexuniverse.com/publications/journalofindexes/joi-articles/2049.html (emphasis added).

2. FISHER, supra note 80 , at 10

83. Actually, the number of banks changes from currency to currency and is not static. Currently there are eighteen banks on the USD panel, U.S. Dollar Panel, BBA LIBOR, http://www.bbalibor.com/panels/usd (last updated May 2012), but there were sixteen at the time of the alleged manipulation, and there have been as many as twenty at one time. The Swedish krona, for example, currently has only six panel banks. Swedish Krona Panel, BBA LIBOR,
http://www.bbalibor.com/panels/sek (last updated May 2012).

84. Libor is directly managed by BBA Libor Ltd., a subsidiary of the BBA with an independent board.

85. Understanding the Construction and Operation of BBA Libor-Strengthening for the Future, BRITISH BANKERS' ASS'N (June 10, 2008), http://www.aciforex.org/docs/markettopics/ 20080610_BBA comments_on_Libor_fixing.pdf.

86. Id. $\S 3.1$; Frequently Asked Questions (FAQs), BBA LIBOR, http://www.bbalibor.com/ bbalibor-explained/fags (last visited Oct. 10, 2012).

87. The Basics, supra note 4. methodology the same from day to day, nor provide the BBA with an explanation of the methodology.

For other questions, the BBA may provide guidance. Suppose a bank received a cheap loan under very peculiar circumstances, perhaps from a client trying to show a vote of confidence. Is that a reasonable basis on which to submit a low quote? ${ }^{88}$ Or suppose a bank is able to borrow from its government at low rates during a time of crisis. Should that go into the Libor rate? ${ }^{89}$ Ambiguities abound, some of which are resolved by the panel banks and some of which are resolved by the BBA.

The submitted quotes are based on the bank's own private data, and the bank is normally not required to substantiate its submission, but there is some quality control. Of the quotes submitted, the interquartile mean is calculated by discarding the four highest and lowest quotes and averaging the middle quotes. The BBA can subject panel banks to inquiry for quotes that the staff-tipped off by publicly available algorithms - determines to be suspicious. In principle a fraudulent quote could result in a bank's ejection from the panel, but investigations are rare and no bank has ever been disciplined in that way.

Thus, Libor is calculated on the basis of a dozen or so banks' self-reported estimates. The banks and the BBA use their judgment to interpret the question and the data. There is substantial room for discretion and relatively little for third-party oversight.

Numerous commentators have called for reform or regulation of Libor, implicitly accepting the myth of objectivity as a background premise. For example, Bloomberg CEO Daniel Doctoroff recently wrote: "Benchmarks such as Libor that rely on subjective assessments ... simply cannot accurately reflect market realities." ${ }^{, 90}$ If only Libor were objective like other indices, they seem to suggest, the world would be much better.

Though distinguishing Libor as an outlier may be comforting, Libor is not unique in incorporating subjective intervention and judgment into its process. The subjectivity built into Libor, though surprising, is not itself the explanation for any manipulative activity, since in several respects all indices - to greater and lesser degrees - function the same way. ${ }^{91}$

88. Yes, it is. Interview with John Ewan, Managing Director, BBA Libor (June 15, 2011).

89. No, it should not. Definitions, BBA LIBOR, http://www.bbalibor.com/bbaliborexplained/definitions (last visited Oct. 10, 2012)

90. Daniel L. Doctoroff, Op-Ed., A Market Alternative to Libor, WALL St. J., Aug. 2, 2012, at Al1, http://online.wsj.com/article/SB10000872396390443687504577563391057853800.html. Doctoroff identifies other problems, including conflicts of interest, that do not implicate subjectivity. See also Hannah Kuchler, BoE Governor Urges Reform of Libor, FIN. TIMES (June 29, 2012), http://www.ft.com/cms/s/0/7a76a74a-cld2-1 lel-b76a-00144feabdc0.html (reporting that Bank of England governor believes that Libor should be based on actual transactions rather than estimate).

91. See Int'l Org. of Sec. Comm'ns, Discussion Paper on Benchmarks 4 (2012) (on file with author) (surveying the ubiquity of subjectivity in all indices and concluding that "[t]he criteria for submitting data was not always objective, with many surveys calling for judgments and subjective rates or prices... The composition and rebalancing rules ... seem to be largely discretionary."). 
First, index methodologies are goal-oriented, and require constant updating in light of the index's goals. Human judgment is required to set the index's goals and to evaluate methodologies that suit it. While Fisher conceived of index providers as reporting on the single center of a moving pool of data, real index production requires providers to take on the normative and expressive task of defining the center.

Second, an index provider may legitimately decide to reduce the accuracy of its index. In fact, index providers must balance a number of incommensurable goods, including accuracy, tradability, and consistency. ${ }^{92}$ No index can maximize every value, and index providers must make tradeoffs among at least these three. Therefore, if two indices both purport to report on, say, oil prices, we should not be surprised or offended if they deliver very different answers about the market trends; constructing an index requires the subjective choice of which values to vindicate, knowing the effect this will have on users.

Third, the data never speaks for itself; human interpretation and editorial content are ubiquitous in the daily function of indices, contrary to Goldberg's characterization. Once an index's method and values are fixed, few indiceseven so-called "market-driven" indices — operate for long without human data gathering or analysis.

\section{Goal-Oriented Methodologies}

Providing an index is a goal oriented activity. Operational challenges and ambiguities can only be resolved by human beings with the index's object in mind. ${ }^{93}$ To effectively steward an index is to be clear on what the index is meant to represent. Contrary to myth, there is no "statistically correct" way to transform data or maintain an index without consideration of what that index is meant to convey and the purposes it will serve. ${ }^{94}$

For example, the S\&P 500 is an indicator and bellwether of blue-chip America, meant to track the most significant large-capitalization firms in the

92. More goals still can be imagined. The decennial census is conducted through a head-byhead count of Americans, rather than statistical sampling, even though the latter would probably be cheaper and more accurate. Although some argue that this practice is preserved precisely in order to undermine accuracy, see Press Release, Rep. Nancy Pelosi, Supporting Plan for a Fair and Accurate Census in 2000 (Apr. 1, 1998), http://pelosi.house.gov/pressarchives/releases/prcensus.htm, it may be that this method privileges other values.

93. Albert Neubert, Not So Fast, J. INDEXES, Nov./Dec. 2006, http://www.indexuniverse.com/ publications/journalofindexes/joi-articles/2317-not-so-fast.html (describing index invention and testing).

94. For an early argument that indices are only the data they aggregate, without reference to purpose, see WILLFORD I. KING, INDEX NUMBERS ELUCIDATED (1930). See also Milton Gilbert et al.,

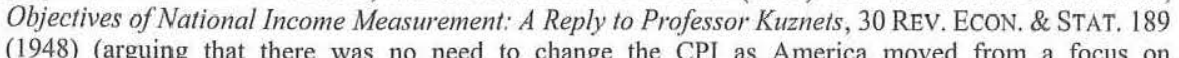
(1948) (arguing that there was no need to change the CPI as America moved from a focus on production, during the Depression, to welfare in the early post-war period). leading U.S. industries. ${ }^{95}$ As companies grow and shrink, the dataset for calculating such an index must change ${ }^{96}$ and the appropriate changes are not self-evident. The S\&P 500 component companies tend to be large, but not the largest 500 on the New York Stock Exchange. ${ }^{97}$ They are selected through additional filters, all subject to human discretion. For example, the S\&P 500 imposes profitability and domicile requirements, but its selection committee waives them on a case-by-case basis for popular or important firms. ${ }^{98}$

In addition to the selection criteria, the committee must decide on selection frequency. If membership in the S\&P 500 is changed only once per century, it will become a reliquary of dead securities. Yet updating the pool of firms every day would make it a "soup de jour" of American industry. There is not one perfect rate of change, and each point on the spectrum reflects the provider's judgment as to the index's purpose.

Interpretive discretion is essential even to indices self-described as rulegoverned and lacking in discretion. ${ }^{99}$ For example, Chinese firms have lately obtained listings on U.S. exchanges by engineering acquisition by moribund, yet still listed, U.S. companies. ${ }^{100}$ All indices that track U.S. companies, including the Russell 3000, which prides itself on tracking the largest 3000 U.S. companies without exception, had to decide whether such firms continued to be "U.S." companies. ${ }^{101}$

Even seemingly mundane mathematical operations can involve profound policy choices, and realizing that indices are goal-oriented can help one to disentangle specious arguments for index "improvement." For instance, in 1996, a Senate-appointed commission identified "several categories or types of

95. S\&P 500 Equity Indices, S\&P Dow JONES INDICES, http://www.standardandpoors.com/ indices/main/en/us (last visited Oct. 10, 2012).

96. See Kelly Haughton, Provisionally Speaking, J. INDEXES, Jan./Feb. 2006, ("Small-cap
managers once held Dell; however, it hardly fits that category any longer, Growth managers once held Pfizer; today this stock is held primarily by value managers. Therefore, by nature, the indexes tha properly benchmark these active managers have higher turnover than the broad-market indexes.").

97. The largest 500 U.S.-domiciled companies are better found through the Fortune 500. For comparison between the Fortune 500 and the S\&P 500, see Robert Arnott \& Li-Lan Kuo, Selection Bias, J. INDEXES, Sept./Oct. 2011, http://www.indexuniverse.com/publications/journalofindexes/joi-articles/ 9743-selection-bias.html.

98. S\&P U.S. Indices Methodology, STANDARD \& POOR's 5-7 (June 2012), http://www.standardandpoors.com/indices/articles/en/us/?articleType=PDF\&assetID=1221189509652.

99. See also Emma Boyde, Index Providers Tweak Rules as Investors Raise Concerns, FIN TiMES (Nov. 18, 2011, 1:08 PM), http://www.ft.com/intl/cms/s/0/b02adf58-092e-11e1-8e8600144feabdc0.html ("'You have rules, but in the real world there will always be exceptions to the rules. Rules have to evolve over time,' says Dimitris Melas, MSCI executive director and global head of new product research.").

100. Id. ('“'We have had a huge amount of debate about what is and what is not a US company,'says [David] Blitzer [chairman of S\&P's index committee], adding that it had been decided
that the Chines companies were not,") (the Chinese companies were not."),

101. Id. ("However, Russell, despite its strict rule-based philosophy, still tweaked its rules after the slew of so-called backdoor listings by Chinese companies on to US markets. 'Sometimes thing catch you by surprise,' says [Russell's director of index research] ....."). 
potential bias" in the CPI. ${ }^{102}$ The committee found that the CPI overstated changes in the cost of living because consumers avoided many price increases by substituting other goods. The committee also argued that price increases may not sufficiently reflect increases in the quality and availability of new goods. ${ }^{103}$ Even if the on-the-shelf price of mousetraps increases, for example, they may be considerably better mousetraps than last year's model. It may appear that the consumer pays more for the same, while she really pays more for more. Thus, many price increases do not change consumer welfare or real consumption.

Alan Greenspan testified before the congressional budget committees that they could save $\$ 150$ billion over five years by "correcting" CPI. ${ }^{104}$ Dale Jorgenson estimated that the CPI's treatment of housing costs from 1968 to 1982 was an "error" that might be worth $25 \%$ of the federal deficit by the mid1990s. ${ }^{105}$ As a result, in 1999 the Bureau of Labor Statistics began using a geometric mean instead of an arithmetic mean to calculate the components of the CPI. ${ }^{106}$ This fulfilled the Boskin Report's promise of more fairly representing unrecorded improvements in consumer welfare.

Talk of correction and error fit well if one believes that there is a gold standard by which methodologies are judged, and from which they can objectively deviate. ${ }^{107}$ Yet, methodological shifts may also imply changes in the index's purpose. As CPI adopted controls for unpriced quality increases, it arguably transitioned from a consumer price index to a consumer welfare or utility index. Prior to the Boskin Report, an increase in CPI represented an increase in the cost of buying what consumers bought before, regardless of whether their consumption had changed. Today, an increase in CPI represents an increased cost of keeping consumers happy, through whatever purchases.

102. See Boskin Report, supra note 23, at 7 .

103. This argument has long had its critics both as it relates to consumer satisfaction, Milton Gilbert, Quality Changes and Index Numbers, 9 ECON. DEv. \& CULTURAL CHANGE 287, 291 (1961) [hereinafter Gilbert, Quality Changes] (criticizing theory for implying that "if someone gives up smoking and gets an equivalent sense of satisfaction from this self-denial, he has maintained his real consumption and benefited from price decline"), and aggregate production, Milton Gilbert, Quality Change and Index Numbers: The Reply, MONTHLY LAB. REV. (Bureau of Labor Statistics), May 1962, 544 [hereinafter Gilbert, Reply]

04. Adam Clymer, As Parties Skirmish Over Budget, Greenspan Offers Painless Cure, N.Y. TIMES, Jan. 11, 1995, at Al, http://www.nytimes.com/1995/01/11/us/104th-congress-overview-parties-

105. Consumer Price Index: Hearings Before the S. Comm. on Finance, 104th Cong. 2, 40 (1995) (statement of Dale Jorgenson).

106. Kenneth V. Dalton, John S. Greenlees \& Kenneth J. Stewart, Incorporating a Geometric Mean Formula Into the CPI, MONTHLY LAB. REv. (Bureau of Labor Statistics), Oct. 1998, at 3. But see GETING PRICES RIGHT, supra note 23 (disputing the Bosk

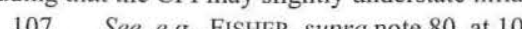

This represents a change in the goal of the index, rather than a correction of an error. ${ }^{108}$

The move to a geometric mean in the CPI lowered government outlays and union wages, while raising taxes, a result with significant political valence. This is why changes in index methodology can stir opposition from those with little interest in perfecting the science of statistics. Bill Gross, founder and co$\mathrm{CIO}$ of PIMCO, the world's largest bond fund described the change: "The CPI as calculated may not be a conspiracy, but it's definitely a con job foisted on an unwitting public ...." ${ }^{109}$ Labor unions, long involved in index policy, opposec the change. ${ }^{110}$ Alterations in index methodology create winners and losers among those who relied on the previous methodology. The possibility for these shifts is an intrinsic part of index production. Ultimately, the shifts in CPI illustrate how data selection and methodology are nested within an index's purpose, and how it is impossible to judge its propriety without reference to them.

\section{Accuracy: One Virtue Among Many}

Even if it is clear what an index is attempting to illustrate- be it consume price, consumer welfare, or whatever else - it may seem that accurate portrayal of that subject is singularly good. Yet, it is both common and essential for index providers to deliberately reduce the accuracy of their index. In fact, al indices exist on a benchmarking spectrum where accuracy is balanced against an index's other legitimate goals, including tradability and consistency. To pick a place on that spectrum is to make a policy choice about what social benefits an index is meant to realize and who its key constituents are. Contrary to myth, there is no ideal level of accuracy for an index without consideration of whom the index is meant to serve and how.

Recall that indices are used as investment blueprints, contract referents, and information sources. These uses place different values on accuracy. Want to know the state of the Polish economy so that you can decide whether to start a new restaurant in Warsaw? There is an index that can help you. ${ }^{111}$ But that same index might let another user, a fund manager, set up a fund representing

108. Nor does it represent the creation of an error, notwithstanding arguments to the contrary For an argument against such an approach as a reflection of consumer utility, see Gilbert, Quality Changes, supra note 103, at 291; for an argument against it as a reflection of aggregate production, se Gilbert, Reply, supra note 103, at 544-45

109. Bill Gross, Haute Con Job, INVESTMENT OUTLOOK (Oct. 2004), http://www.pimco.com/ EN/Insights/Pages/IO_Oct_2004.aspx.

110. See STAPLEFORD, supra note 50, at 356 (2009) ("Union economists recognized (how could they not?) that the main effect of adopting a constant-utility approach would be to lower the index 0 adjust for alleged consumer substitution, new kinds of goods, and the quality improvements that were (supposedy) missed by current methods. ") 111. Warsaw Stock Exchange WIG Total Return Index, BLOOMBERG,
http//www.bloomberg com/quote/WIG:IND (last visited Nov, 14, 2012). 
the Polish economy. For the restaurateur, an accurate, up-to-date index would be of great value. For a fund manager, though, a continuously updating snapshot of the Polish economy could be a terrible index. That is because funds care about transaction costs and transactions costs may be inversely correlated with accuracy.

Beyond mere brokerage fees, index funds suffer enormous costs due to opportunistic arbitrageurs. When an index announces that a given company will be added to the index, index funds are obliged to purchase the company. Index funds typically rebalance their portfolio when the change becomes effective, rather than when it is announced. Arbitrageurs, however, are free to bid up (or down) the price of the security from the date of the announcement, knowing full well that many index funds will soon need to buy or sell the security. The result is that index funds pay more when they buy and receive less when they sell than they otherwise would. The costs of this arbitrage are enormous. ${ }^{112}$ By contrast, the Dow Jones Industrial Average has made no changes since 2009, and only 48 in its 115-year history. Its accuracy as a bellwether is sometimes disputed, but the transaction costs of use are small. Different users may prefer different tradeoffs between accuracy and consistency, given the costs the latter creates.

There are also potential tradeoffs between accuracy and tradability. The Warsaw fund covers all listed Polish companies. Some of these companies may be small and thinly traded. It may be difficult for the fund manager to buy the representative quantity of shares prescribed by the index without affecting the price of the shares. A fund manager might be pleased if the index left off small, illiquid assets at the expense of accuracy.

Tradability and consistency also matter to those who use financial indices as contract referents. Consider how Platts modifies its benchmarks over time. Oil from the Ekofisk region of the North Sea has traditionally traded for a higher price, and traded separately from Oseberg, Forties, and Brent oils. In 2007, Platts decided to include Ekofisk oil with the other three into its Brent index, ${ }^{113}$ which acts as the settlement price of NYMEX Brent futures. ${ }^{114}$ Though Ekofisk is chemically different from the others and generally trades at higher prices, including it increased the volume of oil within the category, which improved liquidity. Platts made a policy tradeoff between being an

112. One study found that index fund investors in the Russell 2000 alone lost $\$ 560$ million, or $1.30 \%$ of their value, per year due to arbitrage effects. Honghui Chen, Gregory Noronha \& Vijay Singal, Index Changes and Losses to Index Fund Investors, 62 FIN. ANALYSTS J. 31, 35 (2006). Loss statistics rise precipitously if assets non-passively indexed to the Russell 2000 are included $(\$ 4.86$ billion per year), or if arbitrage statistics for passively indexed S\&P 500 funds are included ( $\$ 1.32$ billion per year).

113. Bassam Fattouh, An Anatomy of the Crude Pricing System 38 (Oxford Inst. for Energy Studies Working Paper No. 40, 2011), http://www.oxfordenergy.org/wpcms/wp-content/uploads/2011/ 114. Brent 25-Day (Platts) Futures, CME GROUP, http://www.cmegroup.com/trading/
energy/crude-oil/brent-25-day-platts-futures_contract_specifications.html (last visited March 3, 2012). accurate benchmark of Brent, faithfully tracking the represented material, and redefining Brent to improve tradability for Brent-traders.

Frequent and comprehensive updating is valuable for users who use the index as a source of information, but it is injurious to users who employ the index as a blueprint for an investment strategy. Index providers are conscientious of the tradeoff between accuracy, which they cal "benchmarking," and tradability and consistency, which are together called "investability." 115 An index cannot be a perfect benchmark and perfectly investable, so providers must run their index with one or more constituencies in mind.

Parties may disagree with the many ways that index providers exercise their judgment and discretion, but judgment itself is essential to the operation of indices and important for the benefits they provide-particularly in those cases where reasonable people might disagree. ${ }^{116}$ This understanding of indexing illustrates the virtues of the price term at issue in Gulf Oil. ${ }^{117}$ In that case, the parties agreed to use Platts's West Texas Sour oil price in their supply contract. The market fractured when the government eased price controls on oil production in excess of 1972 levels. Chemically identical oils, which may even have come from the same well, could suddenly command a higher price in the market because of regulatory status. Unfortunately for Gulf Oil, Platts excluded the new oil's sale prices from its existing oil price index. ${ }^{118}$

A decision as to relevance had to be made by Platts, and no mechanical operation could serve this function. This judgment may actually have been one reason the parties used the Platts price in their contract. The parties left to Platts the task of trading off accuracy, tradability, and consistency for them. Is "new oil" part of the market for West Texas Crude? Reasonable parties could disagree, but by excluding it, Platts provided an answer informed by its sense of what tradeoffs Platts's users would want and expect.

Indeed, to index users, indices' imbedded discretion may be their greatest virtue, rather than a vice. Parties may wish to outsource decision making to the index provider, which is likely an industry expert with a reputation for the values it weighs in responding to change. The value of indices in contracts thus depends on their ability to accommodate change through judgment and discretion.

115. Telephone interview with David Blitzer, Managing Director and Chairman of the Index with Alex Matturri, Chief Executive Officer, S\&P Dow Jones Indices (Dec. 19, 2011).

116. See Verstein, supra note 47

17. Eastern Air Lines, Inc. v. Gulf Oil Corp., 415 F. Supp. 429, 433 (S.D. Fla. 1975).

118. Id. at 434 . 


\section{Data: No Mathematics Without Judgment}

U.S. Commodity Futures Trading Commission (CFTC) Chairman Gary Gensler has stated: "To be reliable, indices have to be transaction-based an transparent." 119 Yet, even transaction-based indices are mediated by human editors who organize their data into categories.

For instance, Platts has provided market-based oil price data, based on actual transactions, for more than one hundred years. Yet its editors do not contact every oil buyer and seller in order to ascertain prices; they must be selective in how they obtain and weigh data in order to control submission quality. Moreover, editors estimate the value of irregular or unsold supply where price data is not yet available. ${ }^{120}$ Platts even provides an index value "in the complete absence of trade.",121

The data that index providers gather, and how they organize it, represents subjective judgments about the market. The decision to count many things separately or instead to combine them into one category is a subjective judgment about the relevance of their similarities and differences, for which there can be no neutral approach. While Platts once tabulated Ekofisk prices separately from Brent, considering it sufficiently distinct as to warrant its own category in the ledger, Platts now includes Ekofisk as just one type of oil within its Brent index. This change necessarily involved editors' sense that Ekofisk was, or had become, conceptually similar to the other oils in the index. The ways in which data is gathered and organized can have profound implications for the subsequent analysis of that data. ${ }^{122}$ The normative judgments required to organize data acquisition in this way inevitably influence analysis by the provider and the public.

Daily data interpretation involves market savvy and judgment. Each day NYMEX must calculate the closing prices of commodities traded on its exchange. Sometimes this is impossible because, in NYMEX's opinion, there are simply too few trades to make an assessment. ${ }^{123}$ The day's closing market price cannot be obtained simply by checking the last sale of the day, because this might represent a peculiar trade that did not accurately reflect the market. But prioritizing trades that reflect the market requires a normative judgment of

19. Peter Eavis \& Nathaniel Popper, Libor Scandal Shows Many Flaws in Rate-Setting, N.Y IMES DEALBOOK (July 19, 2012, 7:34 PM), http://dealbook.nytimes.com/2012/07/19/libor-scandalhows-many-flaws-in-rate-setting/.

20. See The Western World's Unsung 'Energy Czar,' 11 NAT'L J. 1279, 1279 (1979) (“Each business day, [the Platts editorial director] issues his judgments of the approximate value of oil aroun the world: a cargo of Saudi Arabian crude in Singapore, a tanker of gasoline in the Bahamas,

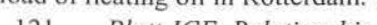

121. Platt-ICE Relationship: Frequently Asked Questions, PLATTS, http://www.platts.com/

22. PORTER, supra note 77 , at $41-42$. 2007).

23. N.Y. Mercantile Exch., Inc. v. Intercontinental Exch., Inc., 497 F.3d 109, 111 (2d Cir what the normal market ought to look like. In those cases, NYMEX's "work appears closer to creation, to making predictions of expected values." 124

Subjective judgment is likewise present in weighting data. For example, a company issuing warrants-rights to purchase stock-may see its share price decline due to simple dilution. An index provider will try to negate any dilutive change in stock price, to prevent a cosmetic change from influencing the index output value. Yet, it is also possible that the drop in the share price reflects the market's belief that issuing warrants is unwise. Thus, even simply incorporating public stock prices requires index providers to parse conflicting interpretations and form opinions about which corporate decisions are cosmetic and which are unwise. Index providers utilize powerful mathematical systems, but human interpretation is creative and determinative in daily operations.

II. How Indices Fail

\section{A. Taxonomy}

The number and variety of indices is daunting, and it may seem that it is impossible to organize them or even define their boundaries. This Part develops a taxonomy of financial indices with the explanatory power to illuminate the different motivations for index production, the risk profiles attendant to different indices, and the applicable solutions to those risks. This grammar of index analysis shows the interconnections between index motivations, risks, and solutions and provides a roadmap for preventing index failures. Appendix A provides a summary chart of this taxonomy.

Broadly speaking, there are three basic forms of indices. Public indices, such as the WPI, GDP, and corporate governance indices, all serve a public purpose of providing information without the ambition to recoup profits. These public-minded indices are policy-oriented and responsive to their creators' agendas rather than profit. Many are provided by the government, but universities, non-profits, and individuals also provide public indices.

Product index providers create indices as their primary business. They provide the index and seek to earn profits by charging users for the privilege of the index's use. They make and sell their product-indices-just as other firms make and sell widgets. The S\&P 500 and Platts are both product indices.

Byproduct index providers produce the index as an incident to some other profit-making activity. ${ }^{125}$ For example, the Libor panel banks help to create Libor and the New York Mercantile Exchange creates the NYMEX index, but neither is primarily motivated by the desire to sell the use of their index.

124. Id. at 116.
125. On the distinction between production and byproduction, see Bruce H. Kobayashi \& Larry E. Ribstein, Law as a ByProduct: Theories of Private Law Production (Illinois Law, Behav. \& Soc. Sci. Research, Research Paper No. LBSS11-27), http://ssrn.com/abstract=1884985. 
International banks have always used Libor to support other products - at first loans, and now swaps - rather than as a standalone product. Byproduct indices exist in order to serve some alternative commercial purpose of their providers, and their creators may not even consider themselves to be in the indexing business.

The explanatory power of this taxonomy resides in its ability to illuminate the interconnections between index producer motivations, index risks, and index solutions.

\section{B. Provider Motivation}

In this Part, we survey the different motivations for index production. We show that specific producer motivations can be broadly understood as driving the taxonomy outlined above and as defining each index model.

\section{Share}

Some index providers wish to share the information with others. The most important producer of such indices is the government. The Senate resolved in 1902 to create the earliest federal index, a progenitor of the Producer Price Index, to investigate the effects of tariff laws upon trade, development, production, and prices. ${ }^{126}$ Since that time, the Bureau of Labor Statistics ("BLS") has provided dozens of indices such as the Consumer Price Index meant to inform "sound decisions in Government and business, or at home, the store, the bank, or just about anywhere." ${ }^{\prime 27}$ Thus, a provider may seek to spread the informational benefits described in Subsection I.A.3 to the index's users. A provider that cares about the coordination problems of others may create an index to spread the benefits discussed in Subsection I.A.2. And contractors frequently make use of CPI as a referent functioning as a price term within the contract. $^{128}$

In addition to facilitating contracting, providers sometimes wish to empower others to discuss and research in a particular way. For example, academic corporate governance indices facilitate investigations into the role of certain corporate bylaw amendments with the goal of advancing the debate within a broad academic community. ${ }^{129}$ Index providers may even be pleased if

126. S. Comm. on Fin., Wholesale Prices, Wages, and Transportation, S. Rep. No. 1394, pt. I (1893); U.S. Department of Labor, Course of Wholesale Prices, 1890-1901, Bulletin No. 39, March 1902, at 205-09.

127. What BLS Does, BUREAU OF LAB. STATS., http://www.bls.gov/jobs/aboutbls.htm (last visited Aug. 28, 2012).

128. How to Use the Consumer Price Index for Escalation, BUREAU OF LAB. STATS., http://www.bls.gov/cpi/cpi1998d.htm (last modified Oct. 16, 2001) ("Escalation agreements often use the CPI-the most widely used measure of price change- to adjust payments for changes in prices.").

129. See generally Sanjai Bhagat et al., The Promise and Peril of Corporate Governance Indices, 108 CoLuM. L. REV. 1803 (2008). investors use the index as a blueprint for investment, following Subsection I.A.1. ${ }^{130}$

We generally associate an information objective with public indices. When the information is shared with users, the public index provider delivers many of the benefits described in Part I, sometimes at great cost, ${ }^{131}$ but without charging for use of its brand, method, or data. This combination of intentional direct production of the index and the absence of index monetization is the hallmark of the public index provider. This is why few public index providers are for-profit firms. Enabling others without explicitly charging is the sort of public good that governments and universities typically desire to produce.

\section{Sell}

Many of the best-known indices, such as the Dow Jones Industrial Average and the S\&P 500, are created primarily as products for sale. Their producers are in the indexing business. Users who want to enjoy the benefits described in Part I may be willing to pay for the use of an index's trademarks, settlement value, methodology, or data.

Many funds are pleased to use indices as blueprints for investment and pay a corresponding fee. ${ }^{132}$ Some funds, such as ETFs, are required under the Investment Company Act to license their index from an unaffiliated thirdparty, ${ }^{133}$ ensuring a captive audience for index sellers.

An index's output value can be used as a settlement value upon which to construct financial instruments, such as options on the S\&P 500, as described in Subsection I.B.1. It is common for options exchanges to pay large commissions for the right to offer index options to their trading customers. Users also pay for information. For more than 100 years, Platts, which produces an industry respected oil price index, has been supported by subscription fees to its pricing services. ${ }^{134}$ Even where the underlying data is otherwise available, indices may charge substantial sums for their aggregation and analysis. ${ }^{135}$

130. See Lucian Bebchuk, Alma Cohen \& Allen Ferrell, What Matters in Corporate Governance?, 22 REV. FIN. STUD. 783, 823-24 (2009).

131. FY 2012 Congressional Budget Justification, BUREAU OF LAB. STATS. (2012), http://www.dol.gov/dol/budget/2012/PDF/CBJ-2012-V3-01.pdf [hereinafter FY 2012 Congressional Budget Justification] (noting that the CPI is calculated through the primary research of thousands of mployees, costing half a billion dollars annually.

132. Vanguard's S\&P 500 Exchange Traded Fund markets itself with the S\&P 500 product name and uses the S\&P 500's calculation methodology to select its investments.

133. Application for Exemption Under Section 6(c) at 21-22, In re Guggenheim Funds (Dec. 15, 2011), http://www.sec.gov/Archives/edgar/data/1167303/000089180411005522/gugg5312240app.htm; Guggenheim Joins Self-Indexing Trend, INDEX UNIVERS (Dec. 2I, http. Wh: Gindexanive

134. See, e.g., Fox Rubin, ICE to Distribute Platts Services, Products Starting in 2012, WALL ST. J. (Dec. 7, 2011, 10:18 AM), http://online.wsj.com/article/BT-CO-20111207-708751.html

135. MSCI Inc., Annual Report (Form 10-K) at 52 (Jan. 31, 2011), http://apps 
It is possible to make ballpark estimates of the rewards providers claim for their indices. S\&P charges an iShares fund a license fee of $.0308 \%$ of fund value. ${ }^{136}$ For 2010 , that meant almost $\$ 22$ million from just one fund, for just one index. ${ }^{137} \mathrm{~S} \& \mathrm{P}$ reports $\$ 1.25$ trillion indexed to its indices. ${ }^{138}$ If it charges similar fees on that entire amount, S\&P would make $\$ 400$ million in annual revenue from indexing. ${ }^{139}$

Further estimates can be divined from MSCI, the only major index provider that makes regular public filings. If its financial information is any indication, then the indexing business is thriving. In 2010, MSCI made $\$ 350$ million in revenue from index-type products. ${ }^{140}$ This represented a $52 \%$ increase in revenue from $2008 .^{141}$ Revenues have increased largely because of an increase in the assets under management of subscribing funds. ${ }^{142}$ The ascendancy of indexed investing has been good for index providers and indexing is currently a high-margin business. ${ }^{143}$ It is profoundly scalable, requiring little marginal investment to maintain another index product similar to an existing one. ${ }^{14}$

3. Use

A third category of index is made for use by a provider that seeks the benefits discussed in Part I. A provider may wish to blueprint its own investments, or create an index term by which to settle its own contracts, or maintain the information gleaned in index production.

MSCI Annual Report] (reporting that two thirds of the $\$ 350$ million in indexing revenue MSCl earned in 2010 came from the sale of data)

136. SPDR S\&P 500 ETF Trust Prospectus, STANDARD \& POOR'S 6 (Jan. 25, 2012), https://www.spdrs.com/library-content/public/SPY\%20Prospectus.pdf [hereinafter Prospectus]. S\&P also receives a fixed annual payment of $\$ 600,000$. Id. at $25-26$. This is an appreciable increase from the early days of index licensing. In S\&P's earliest contract with Vanguard, the latter agreed to pay a mere $\$ 5000$ per year for the use of all the S\&P 500 data and tradenaks. McGraw-Hill Cos. v. Vangurd Index Trust, 139 F. Supp. 2d 544, 549-550 (S.D.N.Y. 2001).

137. Application for Exemption Under Section 6(c), supra note 136, at 17.

138. John Davies, S\&P INDICES, Using ETF's for Strategic Portfolio Construction, http://us.spindices.com/documents/presentations/20120705-presentation-davies-sp-indices-using-etfsstrategic-portfolio-construction.pdf (last visited Nov. 30, 2012).

139. S\&P's total 2010 revenue was $\$ 2.9$ billion. Key Statistics, STANDARD \& POOR's, http://www.standardandpoors.com/about-sp/key-statistics/en/us (last visited Mar. 4, 2012)

140. MSCI Annual Report, supra note 135, at 52

141. Id.

142. Id. at 62 ("The growth [in revenue from index asset-based fees] was attributable to the growth in the average value of assets in ETFs linked to MSCl equity indices."); Guggenheim Joins SelfIndexing Trend, supra note 133 ("Many such arrangements are based on a percentage of assets a fund accumulates. That was perfectly amenable in a world of upstart firms and funds, but looks much less on dollar juggernauts."

143. Telephone interview with Alex Matturri, CEO of S\&P Dow Jones Indices (Dec. 19, 144. Id.
This may be because an index user has decided that it would be nice to avoid the costs of licensing an index. Index licensing amounted to about one third of iShares's total cost to investors, greater than all other expenses excep for the manager's fee. ${ }^{145}$ iShares may suspect that it could make its own index for a fraction of the $\$ 22$ million it pays S\&P. Increasingly, funds are requesting permission from the SEC to make their own indices for their own use. ${ }^{146}$ The prominent Russell indices are produced by Russell Investments, which then offers funds that rely on them. ${ }^{147}$ Other fund advisors are purchasing index providers. ${ }^{148}$ Not only may creating an in-house index be cheaper than paying a licensing fee, it may also be more discreet. A fund manager may wish to run its own indices, keeping the methodology secret, in order to avoid arbitrageurs and copycats. ${ }^{149}$ To the degree the SEC allows these exemptions, increasingly many indices will be produced for internal use, rather than sale. ${ }^{150}$

More often, an index is made for use when nothing on the market quite fits the needs of the user-provider, and she may be best positioned to develop the index. Libor is one example of an index made to suit the users' contracting needs.

Volatile interest rates in the 1980 s drove banks to make variable-rate oans. At first, many floating-rate consumer and some commercial loans would be set in relation to prime, ${ }^{151}$ but as early as the mid-1980s, financial institutions found that offshore interbank rates more closely tracked their own borrowing costs, and that basing loans and derivatives on these rates would reduce their funding risks. ${ }^{152}$ Rather than borrowing from U.S. depositors, the federal government, or other U.S. banks, there was a general move to borrow U.S. dollars from accounts that were legally located abroad, and bank loans increasingly incorporated these funding rates as the variable rate.

45. MSCl Annual Report, supra note 135.

46. Section 6(c) of the Investment Company Act of 1940 permits the SEC to exempt persons, curities, or transactions where it serves the public interest. 15 U.S.C. § 80a-6(c) (2006).

147. See, e.g., HBTA Russell $1000^{*}$ High Beta ETF, RUSSELL ETFS, http://russelletfs.com/Products/HBTA_Overview.aspx (last visited Mar. 4, 2012) (offering an ETF that eks investment results that closely correspond to a Russell-produced index).

148. Alex Ulam, Van Eck Acquires Market Vectors Indices, INDEX UNIVERSE (Nov. 30, 2011), $\mathrm{http}: / /$ www.indexuniverse.com/sections/news/10278-van-eck-acquires-market-vectors-indices- html ("The deal means Van Eck will now be paying licensing fees to a subsidiary instead of an outside mpany.").

149. This is the argument of BlackRock, which currently seeks SEC permission to produce inhouse indices for its funds. Application for an Order Under Section 6(c), In re BlackRock Fund Advisors (Sept. 1, 2011), http://www.sec.gov/Archives/edgar/data/1006249/000119312511239094 150.

The ability to use in-house indices is partially to credit for the appeal of so-called "structured products."

151. Prime, or the prime interest rate, runs about 300 basis points above the federal funds rate, which is the interest rate at which funds on deposit at the Federal Reserve are loaned among banks.

152. Jacob Gyntelberg \& Philip Wooldridge, Interbank Rate Fixings During the Recent Turmoil, BIS Q REV, Mar. 2008, at 59,60. 
Early on, the interest rates on these loans were set based on the cost of funds of the lending banks themselves. So if a syndicate were formed to collectively make a large loan, the loan rate might be written to equal the average cost of funds of all the members of the syndicate. ${ }^{153}$ Because the syndicate would largely borrow in the offshore interbank market, this syndicate rate provided the banks with a measure of security that their funding costs would stay in line with their lending revenues.

However, it was inefficient to calculate these figures for every transaction, collecting data from every lending bank. In 1984, U.K. banks requested that the BBA develop a method to publicly determine the interest rates on syndicated loans. ${ }^{154}$ This BBA method, which would become BBA Libor, proved an attractive shortcut in syndicated lending, largely approximating the funding costs for the participant banks but at much lower cost and greater liquidity. By lending at a rate that aggregated their own costs of borrowing, banks could ensure that the rates at which they lent kept a close relationship to their own borrowing rates. Within two years, this preliminary rate had taken on a form very similar to today's Libor and had been so named. ${ }^{155}$ Increasingly, syndicates referenced the BBA Libor.

Gradually, Libor's dominance moved beyond syndicated lending to encompass all short-term lending contracts. Banks link auto, home, and student loans to Libor. Corporate borrowers hedge or speculate on interest rate movements by buying Libor-linked derivatives, and banks willingly provide them. ${ }^{156}$ Libor is an index that was made from the beginning for use by its providers and not for sale. ${ }^{157}$

Where an index is produced for use by the provider, it will almost inevitably be a byproduct index. Whatever the provider uses the index for will be the product for which the index is produced. For Libor, the banks make money for loans and swaps, and they produce Libor as a means of facilitating that business.

\section{Require}

In some circumstances, a firm may be required to produce an index, sometimes as a result of direct legal regulation. For instance, the New York Mercantile Exchange calculates trade settlement prices by virtue of its status as

153. Richard M. Gray, Libor Market Disruption, MILBANK, TWEED, HADLEY \& MCCLOY LLP (Oct. 28, 2008), http://www.milbank.com/images/content/6/8/688/LIBOR Market_Disruption.pdf

154. Mollenkamp, supra note 1.

155. The Basics, supra note 4; Carsella, supra note 5, at 48.

156. See THE HANDBook OF CURRENCY AND INTEREST RATE RISK MANAGEMENT 2-10 (Robert J. Schwartz \& Clifford W. Smith, Jr. eds., 1990).

156. Carsella, supra note 5, at 48 .

157. The BBA does make a small amount from providing data access, but this dwarfs the importance of Libor for lending and derivatives. an exchange, and those values constitute an index upon which other financial products may be based. ${ }^{158}$

In these cases, the provider does not intend to use the index, to sell it, or to benevolently provide it to the commons. Instead, the index is produced as a necessary step in some other profit-oriented activity. As such, they are like usemotivated indices in that they only arise as byproduct indices. ${ }^{159}$

\section{Risks of Indices}

In the sections below, we argue that financial indices face three principal forms of risk: manipulation, underproduction, and malproduction. In other words, index users may be harmed by affirmative misuse, a dearth of indices, or by the low quality of the indices available. We contend that an account of risk that goes beyond manipulation risk is vital, because many solutions to manipulation actually exacerbate underproduction or malproduction.

Crucially, we show that different index types are vulnerable to different types of risk. Each index type can suffer each type of problem, but the relative likelihood and the optimal solution differs and depends on the motivation of the index provider. Though no one index type is best in all cases, we show that product indices have desirable features that are often underappreciated and that public and byproduct indices are problematic in ways not always considered.

\section{Manipulation}

The manipulation of a financial index-deliberate intervention in the index's inputs, methodology or output to suit the manipulator's interests at the expense of most users-is the most intuitively worrisome form of index failure. We show examples of manipulation from each index type, but we begin with Libor, a byproduct index.

Three theories may explain why panel banks might attempt to manipulate Libor. The "reputational" account suggests that the panel banks were lowballing their quotes in order to appear less financially vulnerable than they were. ${ }^{160}$ Libor quotes are public, so if a bank reported increasing borrowing costs, it would telegraph that lenders were avoiding the bank. During the crisis, no one wanted to be "the next Lehman," and banks had a strong incentive to lie about borrowing costs in order to protect their image. This theory is consistent with the fact that anomalous Libor quotes were generally too low.

According to a second manipulation theory, the "positional" account, banks extracted profit from their clients by manipulating the rate upon which

158. NYMEX, 497 F.3d 109, 118 (2d Cir. 2007).

159. Indeed, both use-production and required-production are conceptually related examples of byproduction.

160. See Mollenkamp, supra note 1. 
their derivative positions were based. If one bank lends more with contracts referencing Libor than it borrows, then it will profit if Libor goes up, and viceversa.

Many commentators are skeptical that banks would have a consistent nonzero net Libor position. ${ }^{161}$ Yet substantial net positions, correlated with the direction of rate irregularities, are exactly what Snider and Youle found. In the first quarter of 2009, Citigroup reported that it "would make \$936 million in net interest revenue if interest rates would fall by 25 basis points a quarter over the next year and $\$ 1,935$ million if they were to fall 1 percent instantaneously."162 The source of such large positions, and their unexpected appearance, was banks' extensive swap operations.

Snider and Youle's findings support the positional theory. They compared banks' swap exposure, as reported to the Fed, to their implied degree of misreporting of borrowing costs. ${ }^{163}$ Suggestively, Snider and Youle found that where Citi had a larger net exposure to Libor, and therefore stood to gain more from a change in Libor, it tended to make larger anomalous quotes. Even more tellingly, Citi had different exposures to different currencies. A rise in Yen Libor would benefit Citi, just as a drop in dollar Libor would hurt Citi. Consistent with a positional theory, Citi's Libor quotes in each currency were often in the same direction that would benefit it.

Both the positional and reputational versions of Libor disruption tend to view manipulation as coming from the top, ${ }^{164}$ but recent details emerging from regulatory investigations suggest a third manipulation theory: the banks may have had poor internal controls, allowing individual traders to manipulate Libor to benefit their own trades. In this "rogue trader" theory, traders enter into small conspiracies with a bank's quote submitters, rather than industry-wide cartels. For example, Barclays Capital's recent settlement with the CFTC indicates that certain swap traders made manipulative requests of the banks' rate submitters. ${ }^{165}$

Banks may, as a whole, lose money from rogue trader manipulation. The Canadian investigation into Royal Bank of Scotland suggests that a bank's

161. Duncan Wood, Libor Fix?, RISK MAGAZINE, July 1, 2011, at 40, http://www.risk.net/ risk-magazine/feature/2081957/libor-fix

162. Snider \& Youle, supra note 14, at 12; see also Abrantes-Metz et al., supra note 22, at 897 ("Based on our evidence, biased signals coming from the individual banks (agent aggregation bias), rate manipulation or collusion appear as one likely answer.").

163. This data is found on Report FR Y-9C, published by the Federal Reserve Board, which must be completed by certain bank holding companies

164. See, e.g., Supplemental Information Regarding Barclays Settlement with the Authorities in Respect of Their Investigations into the Submission of Various Interbank Offered Rates (AMENDED), BARCLAYS 6 (July 3, 2012, 6:10 PM), http://group.barclays.com/news/news-article/1329926004178) navigation-1330349038798 (noting that the President of Barclays Capital may have ordered subordinates to submit lower Libor quotes).

165. Barclays Non-Prosecution Agreement, Appendix A: Statement of Facts, U.S. DEP'T OF JUST. 5 (June 26, 2012), http://www.justice.gov/iso/opa/resources/9312012710173426365941.pdf . traders might request help from a voice broker in tampering with rates. ${ }^{166}$ These brokers help banks to raise money in the money market, and their complicity might make it easier to persuade an unwitting bank treasurer that their potential funding costs actually warrant a higher or lower Libor quote. The bank could borrow at a higher price than warranted, or other traders at the bank could lose, because traders wished to improve their own books. ${ }^{167}$

It is sometimes thought that Libor would be difficult to manipulate because the top and bottom quartile of quotes are eliminated. ${ }^{168}$ So, the argument goes, it would take collusion of more than a quarter of the banks to have any impact on the Libor output value. ${ }^{169}$ This makes manipulation less likely to succeed, and employee-driven manipulation less likely still.

Yet it is far easier to manipulate Libor than it may appear. No conspiracy is required if each bank individually expects to benefit by submitting a false quote. Under the reputational theory, any bank benefits from lowballing its quote, regardless of whether it influences the final quote. As John Ewan, the BBA officer in charge of Libor put it:

It's like a school of fish. When a shark pops up, they all jink at exactly the same moment. You think they are acting in coordination, but they are not. They are all seeing the same stimulus, and reacting in the same way. They want to stay in the school, preferably in the middle of the school befause that is the way they are most likely to not be eaten by a shark. That's not

It is not collusive, but it may be manipulative, and the net result could be an artificial rate.

More importantly, any single bank may influence the Libor even if no other bank has the same idea. Any bank that moves the middle of the pack closer to the outer quartile will affect the average, and any bank that arrives in the excluded outer quartile may push another quote in that would have previously been excluded. This means that any bank may manipulate the Libo

166. See Michael Mackenzie, Libor Probe Shines Light on Voice Brokers, FIN. TIMES (Feb. 16, 2012, 8:45 PM), http://www.ft.com/intt/cms///0/51 abc870-57ee-1 le1-bf61-00144feabdc0.html; Caroline Binham, Brooke Masters \& Megan Murphy, Brokers Suspended in Libor Inquiry, FIN. TIMES (Feb. 8, 2012, 9:31 PM), http://www.ft.com/cms/s/0/7021cdb4-527a-1 lel-ae2c-00144feabdc0.html; see also Application for Order of Additional Production, In re Inquiry Under the Competition Act (Can. Ont. Sup. Ct. J. June 9, 2011) (on file with author) (detailing inquiry into potential conspiracy).

167. The bank or its traders can also profit by providing information, or influence of the rate, to third party traders like hedge funds. This suggests both that extraction can arise from insufficien oversight of unauthorized employee activity, and that extractions can occur through beneficia elationships with other investors, even if the index provider itself did not seek to benefit from its own rading positions.

168. See, e.g., Jacob Gyntelberg \& Philip Wooldridge, Interbank Rate Fixings During the Recent Turmoil, BIS Q. REV., Mar. 2008, at 59, 65 (asserting that manipulation is possible if "contributo (Lehavior."

169. See, e.g., Donia O'Loughlin, At Least Five Banks Manipulated Libor, Boulger, FiN. IMES ADVISOR, July 4, 2012, http://www.ftadviser.com/2012/07/04/regulation/regulators/at-least-five-

70. Interview with John Ewan Managing Director, BBA Libor (June 15, 2011). 
rate in at least one direction unilaterally, notwithstanding the exclusion rule $50 \%$ can move it in either direction, $25 \%$ can manipulate it only upward, and $25 \%$ can move it only downward. ${ }^{171}$ Thus, in a given direction, at least $75 \%$ of the panel banks may unilaterally affect the average by moving the quote in their preferred direction. ${ }^{172}$ Thus it is false to say, as many do, that it would have required coordination amongst more than a quarter of the banks in order to manipulate Libor. Such coordination would be necessary to ensure manipulation power in any direction, but any individual bank can unilaterally move prices in at least one direction. ${ }^{173}$ And a bank with a robust net position would have a strong incentive to misrepresent, without requiring any collusion.

Regardless of the reason, however, the manipulation of Libor is intimately connected with its status as a byproduct. Byproduct providers have severa structural features that make manipulation more likely. First, they tend to draw on privately available data, such as the bank's own funding information. That

171. Imagine a panel of eight banks A, B, C, D, E, F, G, and H, with "true" costs of , $2,3,4,5,6,7$, and 8, respectively, which is their Libor quote on Day 1. Banks C, D, E, and F are included as the middle band and A, B, G, and $\mathrm{H}$ are excluded as outliers, so Day l's Libor output is Libor? Surely, C, D, E, and F can each individually manipulate the outcome either by increasing decreasing their quote $(3+4+5+6+/-\mathrm{n}) / 4=4.5+/-\mathrm{n} / 4$. Of course, there is a limit to how much manipulation can be achieved in this way. If $\mathrm{C}$ lowers its quote to 1 from 3 , it will cease to be part of the middle band. Its quote will be excluded by virtue of being in the bottom quartile. However, B's quote will no longer be part of the outlier pack. The included panel will be B, D, E, and F with quotes $2,4,5$, and 6, respectively, and the day's Libor quote will be 17/4, or 4.25. To be sure, C's manipulation was lunted by the exclusion rule, since she lowered her quote to 1 , but the value submitted to the average dropped only to 2 . But she was still able to unilaterally move the range and lower the average by 0.25 . The same thing would happen if C, D, E, or F were to submit a quote higher than the middle band; they ould be excluded from the calculation, but pull a previously excluded outlier into the band.

The outliers themselves cannot manipulate the Libor by submitting a false quote within the same excluded quartile, but a false quote that moves to the middle band or the other quartile will change the output value. That is, B cannot manipulate the output by submitting a quote of 1 instead of 2 . B's quotes now stands a low to be included. But if B submits a quote of 4 , then she joins the middle band, which the rang if $B$ s, Dits , and $F$ the middle range. Thus the middle range becomes $\mathrm{D}, \mathrm{E}, \mathrm{F}$, and $\mathrm{G}$ with quotes of $4,5,6$, and 7 , respectively. The average value jumps to 5.5 . Again. B's manipulation was dampened by the exclusion system; B's submitted a quote that was 7 higher than her real value, but the Libor average only went $u$ by 1 . Still, she was able to change the value without any assistance.

If the middle range involves more than $50 \%$ of the panel banks, then even more banks may manipulate in either direction. In fact, fewer than $50 \%$ of the bank quotes are excluded because bank with quotes that tie the middle $50 \%$ are included. Thus, from Jan. 2, 2007 until Aug. 8, 2007, 95\% of panel quotes were included in the average. Rosa M. Abrantes-Metz et al., Libor Manipulation?, $36 \mathrm{~J}$. BANKING \& FIN. 136, 145 (2012). During that period, more than $95 \%$ of the time, a bank could influence the Libor total by changing its quote.

ons under which fewer than $75 \%$ of the banks can impact the rate. If all the banks submit a quote of, say, 4 , and then bank A falsely submits 5 , her submission will be the sole outlier. It will be excluded and the average will remain 4. In such cases, no single bank can reliably alter the output value.

173. It goes without saying that banks with opposite signs on their net positions might try to manipulate in opposite directions, and thereby cancel one another out. If banks' incentives were always balanced, his would provide a check on the system. We should be cautious before taking comfort in this possibility, it is easy to imagine reasons that banks' positions might broadly correlate, or that not al banks would manifest manipulative intentions, or both. makes it harder to detect manipulation, lowering the expected impact of sanctions for manipulation. By contrast, many product indices, like the S\&P 500 , draw on public prices and therefore are harder to manipulate.

Second, byproduct indices do not themselves generate a large revenue stream, so index providers have comparatively less to lose by discrediting the index. By contrast, product indices generate revenue streams whose maintenance dilutes their provider's incentive to manipulate.

Third, because byproduct indices are made alongside other product lines, their creators may experience conflicts of interest. It is easier and more tempting for Libor banks or their employees to profit from manipulation since they already deal in loans and swaps. Conversely, a product provider like S\&P could profit from manipulating its indices only if it broadened its business to begin stock-trading. The opportunities for conflict are plainly greater for byproducts.

Though probative, these features are neither necessary for manipulation nor limited to byproduct indices. For example, Platts provides price data through research and expertise that is hard to observe. It could potentially manipulate its price quotes without detection, and in the 1930s, Platts was accused of doing just that in order to facilitate the collusive practices of major oil companies. The United States v. Socony-Vacuum Oil Co. case, a staple of antitrust casebooks, concerned oil companies conspiring to buy up distressedprice oil from the spot market that might have otherwise depressed the market price of their product. ${ }^{174}$ The plaintiffs alleged that Platts enabled the cartel by publishing false price data, allowing the oil companies to buy up the distressed oil at distressed prices but still inputting higher transaction prices when computing the market price. Without Platts's cooperation, the purchase of distressed-priced oil could have lowered the Platts price in a manner identical to how the oil would be sold on the open market. That would automatically lower the price paid by contracts indexed to Platts and indirectly lower the price buyers were willing to pay in the future. With Platts's alleged help, the manipulators could maintain an artificial price.

Even a public index may be manipulated, though typically for different reasons. Public indices are produced for policy reasons. Shifts in those policies could result in shifts in the index's functioning and output, to the benefit of the index providers' goals and the detriment of those depending on the consistency and accuracy of the index. For example, we have already described the ways in which policy objectives drove changes to the construction of $\mathrm{CPI},{ }^{175}$ and other examples are near at hand. ${ }^{176}$

174. United States v, Socony-Vacuum Oil Co., 310 U.S. 150 (1940).

175. See supra notes $106-110$ and accompanying text.

176. See, e.g., The Political Economy of the Consumer Price Index, BRIAN EASTON (July 15 , 2010), http://www.eastonbh.ac.nz/?p=1517 (discussing the political economy of New Zealand's CPI). 
A substantial political science literature is devoted to studying the behavior of publicly minded entities, detailing particular risks inherent in public uses of money and power. ${ }^{177}$ Public indices can become political playthings, subject to alteration for partisan political gain, and unlike product indices, the profit motive does not stand to dilute any manipulative impulse with the prospect of lost future revenue. ${ }^{178}$

\section{Underproduction}

A product is underproduced if the social value of its production exceeds its social cost, but it is nevertheless not produced. ${ }^{179}$ Both index underproduction and malproduction typically result from a particular kind of collective action problem. A classic collective action problem occurs where a) a specific objective is in the interests of all individuals in a benefits of the objective cannot be individually internalized, leading to $\mathrm{c}$ ) each individual attempting to free ride upon others' pursuit of the objective, with the result that d) the objective goes unrealized. ${ }^{180}$

Collective action problems of this sort are to be expected in the context of the production of public or collective goods. ${ }^{181}$ Public goods are those in which an individual consumer's enjoyment of the good is not diminished as the consumer base expands, and from which it is difficult to exclude any

177. See, e.g., Mark Sidel, The Promise and Limits of Collective Action for Nonprofit SelfRegulation: Evidence from Asia (University of lowa Legal Studies Research Paper No. 08-06, 2008), tip.//ssrn.com/abstract $=1090616$

178. See, e.g., Joseph Stiglitz, Distinguished Lecture on Economics in Government: The
Tate of Public Interests: Incentives and Institutions, 12 . some of the features of governance, also applicable to other paradigmatic public 3, 9-11 (1998) (noting the political risks of government failure especially likely; these include the inbic producers, which make to make credible commitments).

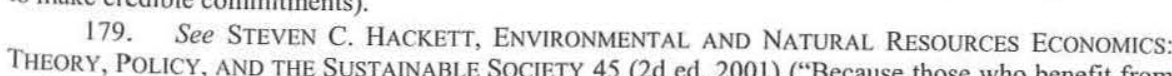
positive externalities do not pay for them, their willingness-to-pay is not included in market demand, and accordingly, market demand is too small."); id. at 47 ("If the benefits flowing to free riders were included in the market, such as through compulsory taxes or user fees, market demand would shift out and a larger equilibrium quantity would result."); WALTER NICHOLSON, MICROECONOMIC THEORY: BASIC PRINCIPLES AND EXTENSIONS 217 (1989) (defining Pareto optimality as "an allocation in which no one person can be made better off without someone being made worse off').

180. The literature on collective action problems is vast. See, e.g., JON ELSTER, ULYSSES AND THE SIRENS: STUDIES IN RATIONALITY AND IRRATIONALITY (1979); MANCUR OLSON, THE LOGIC OF COLLECTIVE ACTION (1965); John P. Dawson, The Self-Serving Intermeddler, 87 HARV. L. REV. 1409 (1974); Barry R. Weingast, The Political Foundations of Democracy and the Rule of Law, 91 AM. POL.
SCI. REV. 245 (1997). Cl. REV. 245 (1997)

181. William H. Oakland, Public Goods, Perfect Competition, and Underproduction, $82 \mathrm{~J}$. POL. ECON, 927, 927 (1974) ("The consensus . . is that private markets will systematically Underprovide for collective goods."); William B. Rubenstein, Why Enable Litigation?: A Positive Externalities Theory of the Small Claims Class Action, 74 UMKC L. REv. 709, 725 (2006) ("[A]II Tragically thecefoty share the good without depleting it and none can be excluded from doing so. dilemma which results is the member has any incentive to bring the case. This is the collective action consumer. ${ }^{182}$ Users of public goods are inclined to 'free ride' without paying for the good, which can make it difficult for the good's provider to recoup the cost of providing it.

Indices resemble public goods, because everyone can enjoy them without diminishing the benefits to others, and because they are nearly non-excludable, with index providers facing difficulties in preventing consumption of their goods and services. Everyone can benefit from a dependable public index for blueprinting, contracting, and information, but no one would like to pay for i unless they must, and it is difficult to fully exclude anyone from the use of an index. Any one of us can compare our portfolio's results to the S\&P 500 or purchase the 500 stocks it contains, just as we can contract to pay our bank Libor $+2 \%$ on our mortgage. Because an index is information, its dissemination cannot be as easily controlled as other products, and it would be practically impossible for $\mathrm{S} \& \mathrm{P}$ or the $\mathrm{BBA}$ to prevent these small, private transactions. Where a provider of a good is unable to exclude users, and hence charge for their use, its incentive to produce is correspondingly lower.

Each of the three index types exists against the backdrop of this collective action problem, and therefore each may be underproduced. This risk is naturally pronounced with product indices because of the difficulty providers face in excluding users. To activate a product market, a provider must be able to protect his index, which in turn requires some degree of enforceable intellectual property rights. With the legal right to exclude users, a product index provider can charge users in order to recoup its costs and sue to prevent infringement, internalizing at least some of the benefits of the index. As long as it is profitable for the provider to generate the index, users can count on getting it.

Of course, these rights can also create their own incentives to underproduce. Indices, once made, are essentially costless to share. Optimally, a provider would charge each user its tiny average cost so that few users would actually be excluded. Yet providers will sometimes find it possible to set prices higher, excluding some. ${ }^{183}$ This restricted output leaves some consumers unsatisfied, representing inefficient "dead-weight" loss to society. This inefficiency is typical of monopolist pricing, ${ }^{184}$ and it follows from the fact that intellectual property rights give a producer a limited monopoly on the index. Anyone who wants to use the S\&P 500 must get permission from S\&P. Some

182. See Andreu Mas-Colell, Michael D. Whinston \& Jerry R. Green, MICROECONOMIC THEORY 359-60 (1995).

183. Economists typically define market power as the ability to maintain prices above a competitive level. See, e.g., Thomas G. Krattenmaker, Robert H. Lande \& Steven C. Salop, Monopoly Power and Market Power in Antitrust Law, 76 GEO. L.J. 241, 247 (1987). The Supreme Court has defined market power as "the ability to raise prices above those that would be charged in a competitive market." NCAA v. Board of Regents, 468 U.S. 85, 109 n.38 (1984); see also William M. Landes \& Richard A. Posner, Market Power in Antitrust Cases, 94 HARV. L. ReV. 937, 977 (1981).

184. EINER Elhauge, United States ANTItrust LAW AND EConomics 6 (2008) 
estimates put the cost of monopolistic behavior by product indices well into the billions of dollars per year. ${ }^{185} \mathrm{~A}$ thriving product market solves the collective action problem but introduces monopoly output restrictions; the balance of these two effects will determine the net effect on underproduction.

Public indices represent a classic form of response to a collective action problem. Certain important public goods are often best produced through government provision by public funds, such as military defense, or natural monopolies, like water utilities. Similarly, some indices can be produced even when the index itself generates no revenue. Revenue-indifferent public index providers do some work in filling gaps in the market, providing an index even where it would be hard to cover its costs through user-revenues. The BLS, for example, spends more than half a billion dollars annually in providing public indices such as the PPI and CPI without attempting to charge for them. ${ }^{186}$ However, there is no reason to think that the government will fully solve the underproduction problem. If provision of the index is not a priority-if, for instance, Congress has cut the department's budget or considers the subject matter politically unattractive - then the mere existence of user utility will not compel the production of the index and underproduction will persist. By contrast, a product provider is more likely to produce an index whenever users would find it valuable.

Moreover, even when public indices are provided, they may simply be unable to perform certain roles. It is hard to imagine BLS creating a Libor substitute, for instance, since many market participants flocked to Libor precisely to avoid government-controlled indices. ${ }^{18}$

The third type of index, byproduct indices, can often escape the collective action problem without resorting to public provision or intellectual property. If an index must be produced in order to pursue other profitable business, then its provider need not find some way to charge for the index itself. However, like a public index provider, a byproduct index provider is unlikely to increase or maintain index production just because users find it valuable. The byproduct index can disappear or remain static, even as demand grows, if the primary product is not sufficiently profitable.

For example, banks publish their prime rate, the rate at which they lend to their best customers, in the course of their business, which allows others to

85. Chicago Bd. of Options Exch., Inc. v. Int'I Sec. Exch., LLC, No. 06-CH-24798, at 14 (IIl. Cir. Ct. July 8, 2010), http://www.sec.gov./comments/sr-ise-2012-022/ise201222-2.pdf (noting that plaintiffs' expert estimated $\$ 2$ to $\$ 9.7$ billion in potential savings to investors arising from interexchange price competition on DJA and S\&P 500 alone).

86. FY 2012 Congressional Budger Jusification, supra note 131, at 2 (\$647 million budget). 187. See, e.g., Michael Carsella, The LIBOR Controversy Part II: Focusing Attention on Basis Risk and Loan Profitability, SECURED LENDER, May/June 2010, at 44, 45, http://www.thesecuredlenderdigital.com/thesecuredlender/20100506 $\mathrm{pg} 46$ ("Libor is a more accurate reflection of the true financing market because it is based on daily market rates for interbank unsecured loans, whereas the FFTR [Federal Funds Target Rate] is laden with the more political goals of controlling inflation and maintaining healthy economic growth (remember, Prime generally mirrors the FFTR plus $3 \%$ )."). construct indices based on this data for free. However, if the bank leaves the primary business line that generates prime data, the data will disappear. Casebooks are replete with the problems observed when banks go out of business, and so stop byproduction of their prime rate. ${ }^{188}$ The reference rate term for the note then has no referent, leaving the borrower's obligations uncertain. Freeriders on byproduct indices risk being left in the lurch.

Moreover, courts seem insufficiently sensitive to the risks faced by byproduct indices. To take one recent example, the New York Mercantile Exchange has sought to treat its NYMEX commodity price index as a product index, charging users for the right to incorporate the index into exchange traded derivatives and denying access to non-payers, but courts have forbidden this move. ${ }^{189}$ Courts, in addressing the risk that NYMEX might cease to produce the index if it cannot monetize it, seem to assume that because the index is produced as an incident of other projects, it is not dependent upon license fee revenue: "NYMEX needs no such incentives here. In order to establish a functioning commodities market it must have a price at which to settle open positions. Furthermore, NYMEX is required by law to record settlement prices ..."190 NYMEX's exchange business, its primary product, entails the creation of the index as a byproduct, and the court is happy to let the law dragoon NYMEX's publication of the index as well.

But the NYMEX court, and courts relying on similar logic, neglect an important danger: preventing the monetization of the NYMEX index leaves the index's existence and quality wholly dependent on the primary product. If the New York Mercantile Exchange's business shrinks, the NYMEX indices may disappear. Even if the indices do not disappear, they may not be improved to the level that they might if doing so brought extra revenue. Cases like NYMEX dilute incentives to maintain or increase the quality of the byproduct.

\section{Malproduction}

Malproduction refers to the inefficient or suboptimal management of an index. For example, index providers can fail to take account of the effect of their changes on their users, neglect their responsibilities for updating the index, or hire cheap but untalented staff. Each type of index is susceptible to

188. See, e.g., Fed. Deposit Ins. Corp. v. Blanton, 918 F.2d 524, 532-33 (5th Cir. 1990) (upholding application of a a substitute prime rate and rejecting the argument "that the applicable postmaturity rate should be one percent because the contract specifies a prematurity rate equal to FNBMidland Prime plus one percent, and upon FNB-Midland's insolvency, FNB-Midland Prime evaporated, leaving one percent").

188. See, e.g., Blanton, 918 F.2d at 532 (applying a substitute prime rate); Montgomery First Corp. v. Caprock Inv. Corp., 89 S.W.3d 179, 186 (Tex. App. 2002) (denying summary judgment to a note holder who failed to establish the amount due on a note, where note had been paid in reference to the base rate of a defunct bank. 189. N.Y. Mercantile Exch., Inc. v. Intercontinental Exch., Inc., 497 F.3d 109 (2d Cir. 2007),
190. Id. at 118. 
malproduction, but the risk of malproduction faced by byproduct indices is the subtlest and most important.

Least likely to malproduce are product indices, which are encouraged by market pressure to maintain index quality for their users. ${ }^{191}$ Though market power may sometimes permit them some slack in their operations, ${ }^{192}$ their only affirmative incentive for malproduction involves cost savings.

Lacking the disciplining effects of the market, a public index provider may be more likely to neglect its operations. Public index malproduction seems to be at the heart of the infamous $A L C O A$ case, in which a supply contract for alumina smelting failed to keep pace with the seller's cost of production. ${ }^{193}$ Although scholars such as Goldberg have criticized the design of the contract, ${ }^{194}$ much of the parties' problem came from the malproduction of a neglected public index. The contract tied ALCOA's costs to WPI-IC, an ancestor of the producer price index. The WPI-IC index may have been a fine choice for a price index in 1967, having been greatly expanded and reclassified only months prior, ${ }^{195}$ but it would proceed to go almost ten years without any substantial update, becoming progressively less relevant. By 1975, the director of the Council on Wage and Price Stability criticized the index for presenting "totally inadequate data." 196 In particular, BLS did not update the index to reflect the massive effect of the 1973 oil embargo on production costs. ${ }^{197}$

It is not that public indices are themselves disposed to malproduction; instead, lack of a profit motive means that discipline must come from the provider's own accountability structure. Byproduct and public indices similarly lack the profit incentive for optimal index production that product indices possess. Because WPI-IC was a public index produced by the government, its continued vitality was bureaucratically and politically contingent.

The most interesting cases of malproduction concern byproduct indices, which will often have an incentive to malproduce. Understanding exactly why, however, requires a more in-depth analysis of the byproduction index model. Byproduction is a species of what economists call "joint production," which involves one firm producing multiple products. ${ }^{198}$ Byproduction is the subset of

191. See infra Part II.D.1.

192. See supra note 183

193. Aluminum Co. of Am. v. Essex Group, Inc., 499 F. Supp. 53 (W.D. Pa. 1980) (ALCOA).

194. GOLDBERG, supra note 40 , at 349 (calling the contract "poorly structured" and "pretty much doomed from the start").

195. JOSEPH P. GOLDBERG \& William T. MOYE, U.S. DEP'T OF LABOR, THE FirST HUNDRED YEARS OF THE BUREAU OF LABOR STATISTICS 235 (1985).

196. Id.

197. Id. at 236 (noting that the Secretary of Labor acknowledged that BLS failed to provide adequate wholesale price data regarding petroleum products)

198. M. Ishaq Nadiri, Joint Production, in 2 The New Palgrave: A Dictionary of Economics 1028 (John Eatwell et al. eds., 1987). joint production in which one product is created largely as a side effect of the inputs made available by the dominant product's creation process. ${ }^{199}$

An example should make the background idea intuitive. A company, seeing a lucrative opportunity for a leather goods business, may begin raising cattle. They will, as a result, have a significant amount of beef available and may begin a subsidiary beef-selling line as a byproduct business. They will do so even if the benefits of selling beef do not match the cost of an independent cattle-raising business for selling beef. They may even give away the beef for free. Consumers, as a result, may often get cheaper beef from the byproducer. $^{200}$ But they should not expect the beef to meet the highest standards of quality. The best leather cows may not make the best beef.

Like beef produced jointly with leather, byproduct indices may often be offered at lower cost to users than product indices would be, but may be managed in whatever way best serves the primary product, which in turn may not be the best for the index user. Libor is produced with information generated through banks' ordinary lending business, and it is used to support their derivatives business. Many users write contracts to Libor without paying for it, like consumers enjoying leftover beef.

For another example, consider the ways that an index affiliated with an exchange might be exploited to benefit the latter. FTSE has recently included questionable Russian firms on its indices even though they differ from the bluechip English firms that make up most of its roster. ${ }^{201}$ This perplexing behavior can be explained as malproduction. Many funds use FTSE indices as blueprints for exposure to high-quality UK companies. If questionable firms are placed on a FTSE index, they may be purchased by investors who rely on the index. FTSE is owned by the London Stock Exchange (LSE), which generates substantial profits from listing fees. If LSE makes clear to firms that listing on the LSE ensures a place on a FTSE index, risky issuers might tender steep listing fees as the price of reaching investors that would previously have avoided them. ${ }^{202}$ This might displease FTSE-linked funds and risk FTSE's

199. See generally John C. Panzar \& Robert D. Willig, Economies of Scope, 71 AM. ECON. REv. 268, 268 (1981) (discussing aspects of joint production and shared inputs) [hereinafter Panzar \& Willig, Economies of Scope]; John C. Panzar \& Robert D. Willig, Economies of Scale in Multi-Output Production, 91 Q. J. ECON. 481, 484 (1977) (discussing joint production).

200. Panzar \& Willig, Economies of Scope, supra note 199, at 268 (providing a theoretical overview of economies of scope); David J. Teece, Economies of Scope and the Scope of the Enterprise, J. ECON. BEHAVIOR \& ORG. 223 (1980).

201. FTSE 100 Reshuffle as Russian Mining Companies Move In, MINDFUL MONEY (Dec. 6, 2011), http://www.mindfulmoney.co.uk/8984/investing-strategy/ftse-100-reshuffle-as-russian-miningcompanies-move-in.html [hereinafter Reshuffle]. See generally Courtney Weaver, Russian Groups Gain a Toehold in FTSE 100, FIN. TIMES (Dec. 7, 2011, 9:08 PM), http://www.ft.com/int $/ \mathrm{cms} / \mathrm{s} / 0 / 99 \mathrm{c} 22806-$

202. See Megan Davies \& Melissa Akin, Fear of Kremlin Whim Stalks Russian FTSE Hopes, REUTERS (Oct. 28, 2011, 9:32 AM), http://uk.reuters.com/article/2011/10/28/uk-russia-ftse-listingsCountry Risk, BLOOMBERG (Dec. 7, 2011, 3.53 PM), http://www evraz-polymetal-join-ftse-100-to-escape-t 
long-term credibility, ${ }^{203}$ but these could be acceptable results for LSE if it sufficiently benefits its listing enterprise. On our terms, LSE would be treating the FTSE as a byproduct in service of its exchange business, which leads to malproduction. As a wave of mergers unite index business with other firms, even product indices will face byproduct-like incentives to malproduce. ${ }^{204}$

\section{Fixing Indices}

This Section presents various solutions to manage the risks associated with indexing. Our taxonomic analysis from earlier bears fruit in this section primarily by illuminating the relationship between the motivations for an index's production and the risks attendant to it, which clarifies how a solution can be carefully tailored to the specific risks a particular index generates.

We consider a full range of responses to indexing risks. In Part A, we evaluate three types of solutions that have attracted attention. We show that market forces and the threat of enforcement can serve a role in reducing malproduction and manipulation, particularly for product indices. However, these tools are of limited utility for addressing underproduction, since you cannot punish an index into existence. Likewise, such discipline may be less useful to improve public and byproduct indices because they are less responsive to profit-based or coercive pressures. We next show how good governance and best practices in index production can help to reduce the risk of malproduction and manipulation, especially for public indices, but that it can be difficult to dictate good governance terms. It is often easier for product providers to design good governance themselves when incentives are aligned. We are therefore cautious about the government prescribing one-size-fits-all rules for index methodologies.

Given this reality, we argue in Part B that the best way to reduce the risks associated with index provision may be to bolster providers' intellectual property rights in their indices. Strengthened intellectual property would provide incentives for product providers to better tend to their indices, and encourage byproduct indices to transition to product status in order to take advantage of increased opportunities for benefit internalization. This would increase index competition, sharpening incentives against underproduction and malproduction while diluting incentives to manipulate.

The current intellectual property regime governing indices fails to provide these incentives. It is weak and incoherent. A better regime would encourage

203. Reshuffle, supra note 201

204. See, e.g., Ann Saphir, CBOE: Only 'Positives' From CME's S\&P Index Deal, ReUTERS (Oct. 5, 2011, 11:08 AM), http://www.reuters.com/article/2011/10/05/cboe-indexesid Ben Harrington, Pearson Sells $5450 \mathrm{~m}$ Stake in FTSE to London Stock Exchange, TeLEGRAPH (Dec. 12, 2011, 8:43 AM), http://www.telegraph.co.uk/finance/markets/8950265/Pearson-sells-450m-stake-in-
FTSE-to-London-Stock-Exchange.html byproduct producers to operate more like product indices. The combination of intellectual property with market pressure, enforcement, and good governance may hold promise for addressing the most difficult byproduct problems, such as a Libor manipulation. This argument has been not only been overlooked but in some cases actively blocked by the current intellectual property regime, to the detriment of providers and consumers alike.

\section{A. Evaluating Solutions}

\section{Market Solutions}

Two features of markets can potentially manage index risk. First, market competition will discipline product index providers to maintain quality on pain of losing their users to another provider. To retain users, a provider must limit malproduction and manipulation. However, the strength of competitive forces will depend on the index provider's stance toward losing its users, and the cost of users transitioning to a new index.

Unfortunately, the cost for users to transition to a new index may be high. Indices enjoy substantial network effects, and so, just as with trading venues, we should expect the dominance of one index in a given niche. ${ }^{205}$ An index may become so dominant that one would give up substantial benefits by opting for a competitor. ${ }^{206}$ Some users may prefer a malproduced or manipulated index to one that is less liquid or well-known. ${ }^{207}$

Risks may be greater for less liquid users. The network effects of indices are particularly apparent in long-term relationships. ${ }^{208}$ Many swaps, corporate bonds, and mortgages are written for terms of decades. Therefore, leaving a bad index could create significant transaction costs as parties renegotiate their contracts to select a new index.

Despite these challenges, competition still sets a boundary on the extent of malproduction. Whatever costs users face in leaving an index can be overcome if a competitor subsidizes escape. ${ }^{209}$ Costs are likely to be high to tip Libor, given the need to renegotiate six million home mortgages. However, another

205. Craig Pirrong, Bund for Glory, or, It's a Long Way to Tip a Market at 3 (Feb. 23, 2005) (unpublished manuscript), http://ssrn.com/abstract=672504 ("Theory predicts that financial markets are 'tippy,' that is, that all trading volume tends to gravitate to a single trading venue.").

206. Cf. Clayton P. Gillette, Lock-in Effects in Law and Norms, 78 B.U. L. REv. 813 (1998); Mark A. Lemley \& David McGowan, Legal Implications of Network Economic Effects, 86 CALIF. L. REV. 479, 562-86 (1998).

207. Telephone interview with John Grout, Policy and Technical Director, Association of Corporate Treasurers (Nov, 8, 2011) (stating that companies don't care about "the nth decimal point" of cost as long as they have a rate they understand).

208. Id.

209. See Pirrong, supra note 205 (German government bonds tipped from LIFFE to Eurex for about $3 \%$ of total costs); see also LIEBOWITZ \& MARGOLIS, supra note 74, at 138 ("Tipping occurs when a product subject to increasing returns generates sufficient momentum in market share that its domination of the market becomes inevitable." 
provider would have an incentive to enter if the benefits of tipping Libor were greater than these attendant costs. ${ }^{210}$ Where indices operate as products, it does not appear that lock-in effects have been problematically strong. Vigorous competition between Dow Jones, S\&P and others for index clients does not seem to have been inhibited by S\&P's larger position.

On the other hand, Libor, a byproduct index, does not directly generate significant fees from users. This means that Libor and other byproduct indices are less likely to be disciplined by competition than product indices. More generally, product index providers rely on users for revenue, but byproduct and public providers do not directly rely on fees from the index. Therefore, the disciplining effect of market competition is both blunted for the latter types of indices and more acute for product indices.

Whatever the incentive effects of the market on the provider, a second market solution exists insofar as users can craft contractual terms to protect themselves from problematic indices. Sophisticated lenders have long included so-called "market disruption" clauses to protect themselves from disruptions to the Libor rate. ${ }^{211}$ A contract might authorize the substitution of a new referent if an index becomes untenable. However, these clauses are typically hard to invoke $\mathrm{e}^{212}$ and often require the agreement of a large majority of a banking syndicate. ${ }^{213}$ Even then, it may be necessary to prove that a market disruption has taken place. ${ }^{214}$ Use of these clauses has accordingly been rare. Prior to the LIBOR disruption, perhaps a half dozen of these clauses had ever been invoked. ${ }^{215}$ Even the events implicated in In re Libor resulted in the invocation of very few of these clauses. ${ }^{216}$

Contractors could negotiate more easily invoked disruption clauses for Libor or any other index, but counterparties will worry that the index is only a

210. Yet even the fee to tip Libor may not be prohibitively high. Mortgage brokers hawk refinancings every few years. If suitably encouraged, they could bring new indices as well as new prices. 211. Financial Crisis Series: Impact on Loans and Credit Markets, Practical LaW COMPANY (Feb 13, 2009), http://us.practicallaw.com/1-384-0310.

212. Wood, supra note 152, at 28 (noting that MDCs "were more habit-forming than useful") 213. Gray, supra note 153, at 3; Philip Rawlings, Market Disruption Clauses in Syndicated Loans, 24 BUTTERWORTHS J. INT. BANK \& FIN. L. 447, 449 (2009).

214. See, e.g., Case C-8/08, T-Mobile Netherlands BV v. Raad van bestuur van de Nederlandse Mededingingsautoriteit, 2009 O.J. C180, 12 (invoking clause); Market Disruption Clauses, BAKER \& MCKENZIE 2 (Oct. 31, 2008), http://www.bakermckenzie.com/files/Publication/42a752c42c81-42ab-828d-50c9f9118cb3/Presentation/PublicationAttachment/350636f4-4028-4e62-a089-

215 7c0 cf7/al_marketdisruptionclauses_oct08.pdf (discussing difficulties with invoking clause).

215. Gray, supra note 153 , at 4

216. Loan Agreement: Borrowing Mechanics, PRACTICAL LAW COMPANY,
http://us.practicallaw.com/3-383-6717 ("However, Lenders rarely http://us.practicallaw.com/3-383-6717 ("However, Lenders rarely invoke this right because .... They may not want to jeopardize their relationship with the borrower."); A. David Reynolds, Disruptions in (June 8,2009$)$, http://us practicallaw.com/4-386-1075. This is perhaps to be expected; the boilerplate that gave rise to disruption clauses was drafted to address index disappearance, not manipulation. Wood supra note 152 at 18 ("The was drafted to address index disappearance, not manipulation. Wood, therefore banks considered that it might be vulnerable to disappearance."). temporary measure in the contract and that the real price term is the substitute term. ${ }^{217}$ Worse yet, contracting to set the substitution conditions, or litigating their use, creates transaction costs of the sort that indices were selected to avoid. ${ }^{218}$

Another limitation to contracting for disruption clauses is the difficulty of detecting profitable index manipulations. Index manipulation will often be hard to detect and still harder to prove. The scale of use of any of the major indices is measured in the trillions of dollars. Even a small adjustment in value could result in millions of dollars of gains over a short period of time. Although the absolute wealth transfer will be large, the index number itself may only deviate slightly, and may appear to be well within the range of ordinary price fluctuations. Thus, many contractors will not know when to invoke a contractual protection, negotiate for them, or shop for another index.

Most importantly, however, the disciplining force of market competition is currently limited because of underproduction. As a public good, indices will often not exist in sufficient number for robust competition to have its salutary effects. Hence, market solutions are unlikely to solve all index problems, but are proportionately more effective where product indices are able to capture large revenues.

\section{Enforcement}

Enforcement, by which we mean private, administrative, and criminal adjudication, plays a role in preventing and remedying index problems, particularly for product indices. In re Libor now involves plenty of pending enforcement. In that class-action lawsuit, interim counsel has been appointed for two classes of aggrieved investors including the City of Baltimore, pension funds, hedge funds, and individual investors alleging either that they purchased or sold Libor-based assets in the over-the-counter market, such as swaps, or on an exchange such as Eurodollar futures, respectively. ${ }^{219}$ The facts allege that the plaintiffs either sold assets at depressed prices, such as Eurodollar futures, or held assets at decreased revenues, such as an interest rate swap.

The resulting legal claims invoke a vast collection of laws: the Sherman Act $;^{220}$ equivalent state law antitrust laws; ${ }^{221}$ federal securities laws; ${ }^{222}$ state

217. Rawlings, supra note 213, at 449 (reporting that borrowers may be resistant to market disfruption clauses that may override the index term too readily, particularly if invocation of the term is difficult to dispute); see also IIG Capital LLC v. Van Der

218. See, e.g. IIG Capital LLC v Van Der Merwe \& Anor, [2008] EWCA (Civ) 542 ; see also Verstein, supra note 47 (showing that the benefits are reduced when contractual principals must also Verstein, supra note 47 (showing that the bent
monitor their specifying agents, including indices).

219. See sources cited supra note 16. The Charles Schwab Fund family is suing separately. See Complaint, Schwab Money Market Fund v. Bank of Am. Corp., No. 3:11-cv-04186-MEJ (N.D. Cal. Aug. 23, 2011) [hereinafter Schwab MMF Complaint].

220. Schwab MMF Complaint 9ा 93-99 (citing 15 U.S.C. § 1 (2012)). 
securities laws; ${ }^{223}$ state torts; ${ }^{224}$ state contract laws; ${ }^{225}$ state unfair business practice laws; ${ }^{226}$ state fraud laws; ${ }^{227}$ the Racketeer Influenced and Corrupt Organizations Act (RICO); ${ }^{228}$ and manipulation in violation of the Commodity Exchange Act. ${ }^{229}$ Criminal, antitrust, and securities agencies from half a dozen countries have subpoenaed and, in some cases, already punished panel banks. ${ }^{230}$

Optimal deterrence often involves forcing actors to internalize the social costs of their behavior. Imposing litigation costs upon product providers will often encourage best practices. Product providers have a robust revenue stream associated with their index. As profit seekers, these providers will try to lower costs, including enforcement-related costs. Threatened with liability for negligent or intentional mismanagement of an index, many product providers will be deterred from wrongdoing.

Optimal deterrence through enforcement is unlikely in cases of byproduct indices like Libor, highlighting the limits of enforcement. It is far more difficult to use enforcement to discipline a byproduct index provider because any credible enforcement activity may lead to over-deterrence and exacerbate underproduction. This is because enforcement imposes on providers the social costs of their indices, but byproduct indices do not directly capture the social benefits of their indices. The potential costs of index dysfunction being

221. Id. ๆๆ 203-09.

222. Id. ๆๆ 117-28 (citing Securities Act of 1933 \$ 11, 15 U.S.C. \$ 77k (2012) (civil liability for false registration statement)); id. $94129-37$ (citing Securities Act of 1933 \$12(a)(2), 15 U.S.C. \$ 771(a)(2) (2012) (civil liability for omission or untrue statement of material fact)); id. ๆ9 138-41 (citing Securities Act of 1933 \$ 15, 15 U.S.C. \$ 770 (2012) (liability of persons controlling anyone liable under

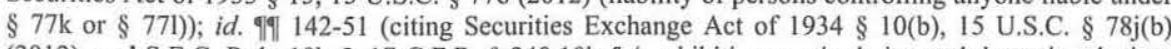
(2012), and S.E.C. Rule 10b-5, 17 C.F.R. § 240.10b-5 (prohibiting manipulative and deceptive devices curity)); id. qqI 152-54 (cing Securities Exchange Act of 1934 $\S 20$ (a), 15 U.S.C. \$ $78 t$ (a) (2012) (controlling person liability)).

223. Id. ๆๆ 185-89 (citing CAL. CORP. CODE \$§ 25400-01 (civil liability for false or misleading tatements or omissions in connections with securities sale))

224. Amended Class Action Complaint 9ף 143-45, Metzler Inv. GmbH v. Credit Suisse, No. 11-MD-2262 (S.D.N.Y. Dec. 23, 2011) [hereinafter Metzler Complaint] (tortious interference with contractual relation); Schwab MMF Complaint, supra note 220, qฮा 100-104 (interference with economic (a) under California law).

225. Schwab MMF Complaint qा 190-95 (breach of implied covenant of good faith); id. शा 196-202 (unjust enrichment); Metzler Complaint, supra note 224, ๆๆ 136-42 (breach of contract).

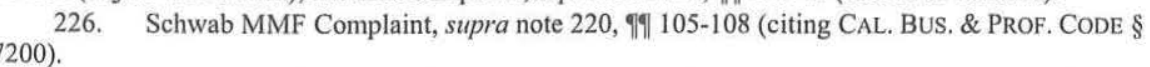

227. Id. ๆๆ 109-16 (citing CAL. CIv. CODE \$§ 1572, 1709, 1710 (fraud, deceit and

228. Id. ๆๆ 155-84 (citing 18 U.S.C. § 1961 et seq. (2012) (prohibiting participation in racketeering activity)).

229. Metzler Complaint, supra note 224, ๆ 115-21 (alleging defendants caused artificial prices on CME, a contract market) (citing 7 U.S.C. $\$ \S 1$ et seq. (2012))

230. Cf. Lindsay Whipp, Tokyo watchdog imposes two sanctions on Citi, FIN. TIMES (Dec. 16, 2011, 5:37 PM), http://www.ft.com/int//cms/s/0/645da6a2-27d6-11e1-a4c4-00144feabdc0.html (stating that Japan's astronornical, ${ }^{231}$ even honest firms may face substantial litigation expenses from meritless lawsuits. ${ }^{232}$ With no index-related revenue, a byproduct provider may decide that providing an index costs more than it contributes to whatever primary activity the index was a byproduct of. Certain Libor panel banks have already withdrawn in the wake of litigation. ${ }^{233}$

Moreover, when enforcement does not over-deter, it may under-deter, because of the practical difficulties of credible punishment. It will generally be hard to detect and prove manipulation, and establish damages ${ }^{234}$ it is especially hard for byproduct indices like Libor, which utilize non-verifiable, proprietary data rather than the public data used in product indices like S\&P 500. Index disruptions of the sort noted in In re Libor may have many causes, and enormous profits can be reaped within the realm of statistically insignificant error.

After proof, there comes punishment. To cause the perpetrators to make victims whole would be an appropriate but devastating remedy. The Financial Times described the potential liability from Libor enforcement as "too catastrophic to impose. ${ }^{, 235}$ The cost of a penalty could easily bankrupt many index providers.

This problem is more severe for byproduct indices because, by definition, the provider has some other line of business that enables the index. Three quarters of the USD Libor panel contributors are Globally Systemically Important Financial Institutions (SIFIs), and almost half of the global SIFIs are USD Libor panel banks. ${ }^{236}$ Especially during a financial crisis, it may be unrealistic to punish such providers at the risk of their collapse. Enforcement can only deter if its threats are credible, but it may be too costly to fully punish

231. Libor Penalty, supra note 20 (noting that Libor manipulation damage could have come to $\$ 1$ trillion).

232. More than a dozen firms have been sued in In re Libor. Consolidated Amended Complaint, In re Libor, No. 1:11-md-02262, 2012 WL 1522306 (S.D.N.Y. Apr. 30, 2012). If only a few banks were involved in the Libor disruption, then the other firms have incurred substantial defense fee by association.

233. Whipp, supra note 230; Stanley Carvalho and David French, Exclusive: Libor Scandal Forces Barclays From UAE Rate Panel-Sources, REUTERS (July 15, 2012, 8:43 AM), http://www.reuters.com/article/2012/07/15/us-banking-libor-eibor-idUSBRE86E03N20120715.

Enforcement could harm product production too, if liability attaches to data providers. Argus, a provider akin to Platts, argued that new CFTC enforcement rules "may unnecessarily chill the voluntary submission of transaction related data by market participants to compilers of price indices." Prohibition on the Employment, or Attempted Employment, of Mas 2ulive and Deceptive Devices and Prohibitio on Price Manipulation, 76 Fed. Reg. 41,408 (July 14, 2011) (promulgating final rules, and describing
comments received).

234. See Rosa M. Abrantes-Metz, Gabriel Rauterberg \& Andrew Verstein, Revolution in W 15 U. PA. J. BUS. L. (forthcoming 2012) (describing the use of screens in pleading).

235. Libor Penalty, supra note 20.

236. Thirteen out of twenty-eight global SIFIs are panel banks, and thirteen out of eighteen panel banks are global SIFls. See Updare gr Grop o , r.121031 lac.pdf. 
index providers who provide other important services. By contrast, a monoline product index might be made to buckle under the weight of liability without compromising the broader financial system.

When the expected cost of enforcement is high, product providers may improve their indices to avoid credible threats of punishment. By contrast punishment may not be credible against byproduct indices, which may be spared the rod if their primary product is socially important. Even when punishment is credible, byproduct providers may sometimes find it cheaper to stop providing the index than to improve it. In either case, the difficulties of detection and proof limit the power of enforcement. Ideally, enforcement would be supplemented by other solutions and by structural improvements intended to make indices more appropriately responsive to enforcement.

\section{Governance}

Good index governance can reduce the risk of index malproduction and manipulation, but there is no such thing as a free lunch. Changes to index practices always create tradeoffs. With even the most attractive solutions creating costs, it may prove difficult for the government to mandate reforms.

Consider six proposed reforms to BBA Libor as an example for how regulators might impose best practices for an index. First, it may seem that banks should submit their Libor quotes anonymously, so as to diminish any reputational motive for lowballing quotes. While such a change would reduce the reputational motivation for manipulation, it would increase the attraction of positional manipulation and rogue trading since it would be harder for the market to scrutinize bank quotes in terms of comparable data.

Second, some banks seem to have allowed extensive interactions between the treasurers who set the Libor quote and the traders who bet on Libor. ${ }^{237}$ It may seem that the government should require banks to create a "Chinese wall" between these groups. Yet this is not obviously better. During the financial crisis, when bank borrowing was thin, determining banks' borrowing rates was difficult, and treasurers may have turned to traders as a source of valuable information on comparable metrics that might bear on the Libor quote.

Such communications would be unnecessary if a third suggestion is adopted: indices like Libor could be based only on actual market transactions, rather than each treasurer's subjective sense of what rate they could get. ${ }^{238}$ But some markets are thinly traded, particularly during a financial crisis. Libor is quoted in 15 maturities in ten currencies. Just what quantity does J.P. Morgan borrow, unsecured, in London, of Swedish krona, with an 11-month maturity,

237. Liam Vaughan \& Katie Linsell, Libor. Flaws Allowed Banks to Rig Rates Without Conspiracy, BLOOMBERG (Jul. 16, 2012, 5:46 AM), http://www.bloomberg.com/news/2012-07-16/liborflaws-allowed-banks-to-rig-rates-without-conspiracy.htm

238. See Eavis \& Popper, supra note 119 (quoting Chairman Gary Gensler). on any given day at 11 a.m.? There may not be an actual market transaction to substantiate the bank's daily quote, but a quote is still required. This is because users - swap participants in particular-want to know the Libor for their transactions. A rate limited to real transactions would be erratic or blank with some frequency.

Fourth, the government might go even further, banning those indices for which reliable market data is not always available. The UK is expected to force Libor to discontinue peculiar offerings like the 11-month Swedish krona rate. ${ }^{239}$ Yet this substitutes malproduction for underproduction, and it is doubtful that the government is better positioned than market participants to decide which individual rates are better unproduced than produced alongside efforts to manage their risks.

Fifth, it may seem that Libor panel banks should be barred from also being Libor users. ${ }^{240}$ While it is true that separating use and production may resolve conflicts of interest, this suggestion nevertheless misunderstands the economics of Libor. For byproduct indices, indirect revenue is the only revenue the index brings. Divestiture without some substitute revenue stream can only lead to underproduction. The banks created Libor almost thirty years ago so that they could use it. If they cannot use it, they may not incur the expense of maintaining it. ${ }^{241}$

Sixth, and finally, submissions could be designed so that manipulation is more difficult or costly. For example, banks might be required to provide whatever data justifies their quote, or they might be required to accept trades or loans at whatever rate they quote. Then banks would be cautious at least to submit higher quotes, lest they be forced to borrow at a higher price. Both of these suggestions would make manipulation more costly, but could exacerbate underproduction since banks may not wish to release proprietary data or make a market for cash they do not want at that time.

The point is not that these practices are inadvisable, only that it is difficult for a third party to determine whether a practice is justified for a given index and how each tradeoff should ideally be made. A government regulator imposing rules is arguably less likely to make the right decisions here than a properly motivated provider of a product index. Product index providers will generally have an incentive to operate in a manner that preserves the value of

239. Theatley Plan for Libor Overhaul in Full, 239. Gonzalo Vina, U.K. Will Implement Wheatley Plan for Libor Oven-10-17/u-k-willBLOOMBERG (Oct. 17, 2012, 11:00 AM), http://www

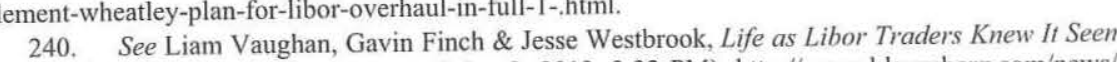
as Abusive by Investigators, BLOOMBERG (Mar. 2, 2012, 3:32 PM), http://www.bloomberg.com/news 2012-03-02/life-as-libor-traders-knew-it-seen-as-abusive-by-collsion-instigators.hts. Relatedly, seems likely that index providers ough to have conflos polies for trading, at a minimum, but the procise lovel and tye If 241. Peter Thai Larsen \& Wayne Arnold, What If Banks Boycott Libor?, REUTERS (July 17 2012, 4:41 PM), http://in reuters.com/article/2012/07/17/idINL4E8IH1HU20120717. 
their product, so they may be expected to take governance seriously. ${ }^{242}$ Even if the mandated governance does not make things worse, any business practice requirement limits the freedom of the provider to exercise its judgment and discretion, which are the essence of an index's operation and the value it adds.

Sometimes the government cannot avoid mandating governance- that is, when the government itself is the provider of a public index. Many users are afraid of government manipulation for political ends; the flight to Libor is partly attributable to banks' distrust of government controlled indices. ${ }^{243}$ In this case, insulated and professionalized indices may be better able to resist political influence and so enjoy greater legitimacy and utility. ${ }^{244}$

In creating new public indices, the government may wish to co-opt other market actors in order to overcome informational deficits. Yet in order to do so the government would require adequate systems of oversight to make sure that it is not an unwitting abettor of manipulation. For example, the government could create a benchmark interest rate index based on Fedwire data to compete with Libor. ${ }^{245}$ In an important study, authors at the Federal Reserve Bank of New York compared Libor rates to the $\$ 2.6$ trillion in daily transactions conducted through Fedwire, which is the Federal Reserve's interbank payment system. ${ }^{246}$ This same method could be used to construct an interbank lending index that would be resilient to political risks from the provider and also based on actual transactions. This is a promising avenue, though it has its own challenges. First, an actual-transaction index may disappoint users when there is no actual transaction upon which to report. Second, this strategy makes banks involuntary byproducers of the new index with no financial interest in its accuracy, and they may act strategically, such as engaging in transactions designed to manipulate the index. ${ }^{247}$ Any new public indices must be carefully protected from these perverse incentives.

If the government is able to overcome governance risks, new public indices could be funded to help solve underproduction and to provide users with an alternative to existing product and byproduct indices. Public indices could provide competition to malproducing indices and help overcome underproduction. Still, it is implausible to rely totally on public provision for society's index needs. Good governance in index production can probably reduce index risks, but it is difficult to design efficient rules from the outside.

242. S\&P, for example, mandates that their index committee members have no trading or sale role within the firm or on their own account. Blitzer interview, supra note 115.

243. Carsella, supra note 187 , at 46.

244. See STAPLEFORD, supra note 50, at 390-99. It is beyond the scope of this paper to fully elaborate how agencies can be designed to resist pressures, but a vast literature in political science, ic choice, and economics confronts these questions.

245. Kuo, Skeie \& Vickery, supra note 4

(twire Funds Service-Annual, FED. RES. BOARD, http://wWw.federalreserve.gov/paymentsystems/fedfunds_ann.htm (last updated Aug. 10, 2012

247. See supra Subsections II.C. 2 \& 3
Providers of product indices have a greater interest in finding credible methodologies and so may be able to design their own good governance more readily than may byproduct providers.

\section{B. The Law of Intellectual Property and Unjust Enrichment}

Market, enforcement, and governance responses are solutions to some index risks, but their effectiveness is limited when most of the indices come from byproduct and public providers. In this Section, however, we argue that the most promising response to the risk of index manipulation is also the best way to manage the risks of index underproduction and malproduction. This solution involves reforming the intellectual property law that governs financial indices, so as to optimize market participants' incentives for index production.

Although all three index types serve important functions, byproduct indices are prone to special risks, such as conflicts of interest. Product indices are not without their own risks, but their profit motive often makes them more responsive to their customers' needs and the law's sanctions. Yet, in recent years, courts have increasingly forced product indices to migrate to a byproduction model. Part 1 of this section describes that forced transition by analyzing recent developments in the law governing indices.

Part 2 urges reform. Financial indices should regain a degree of property protection similar to that which they enjoyed a decade ago and which served well since the early 1980s. Moreover, those substantive rights should be supported on a new doctrinal basis. Rather than returning to the state law doctrines that previously played the role, we should consider tailoring a federal regime for financial indices. Such a regime would do more than allow existing product indices to continue their business; it would permit many byproduct indices to become product indices if they deemed it more efficient. And even those that retained their byproduct model would enjoy stronger incentives to manage their operations responsibly.

\section{State Law Misappropriation}

For decades, product index providers were able to rely on state common law to protect their indices. Today, though, courts are increasingly finding that the Federal Copyright Act preempts state law index protections, but provides none of its own. This section shows that state-law index property protections are doctrinally insecure and theoretically confused because they rest on a flawed analogy between index providers and newsgatherers. Worse yet, the rise of an equally flawed analogy - indices as securities - is rapidly eroding the few property protections indices currently possess. 
i. Indices as "Hot News"

Index providers generally possess the right to control use of their index and its output value. Both property rights find support in the landmark case Standard \& Poor's Corp. v. Commodity Exchange, Inc. (Comex I). ${ }^{248}$ There, Commodity Exchange, Inc. (Comex) developed a futures contract called the "Comex 500 Stock Index" that "essentially duplicate[d] the S\&P 500."249 Comex allowed users to trade futures contracts on the Comex 500, despite S\&P's refusal to grant it a license and without paying S\&P any fees. The court of appeals held that Comex had misappropriated S\&P's property. ${ }^{250}$ Similarly, in Board of Trade of City of Chicago v. Dow Jones \& Company, Inc. $(C B O T),{ }^{251}$ the Illinois Supreme Court ruled that index providers may prevent users from creating contracts settled based on an index, even if users are licensees of the index data.

These cases are the foundation of contemporary index producers' property rights, and the basis of Dow Jones, S\&P and MSCI's indexing business. Yet from the beginning, index rights were problematic due to their characterization as quasi-intellectual property akin to news. Both the Comex I and CBOT courts grounded their decisions in the "hot news doctrine", which originates in International News Service v. Associated Press (INS), a 90-year-old Supreme Court decision finding that International News Service, by speedily publishing stories based on fresh news gathered by other news companies rather than sending their own reporters out for a scoop, had committed tortious misappropriation. ${ }^{252}$ INS upheld a quasi-intellectual property right in certain information because of the effort that went into its acquisition, and because of the unfairness of taking information acquired by others and selling it at a lower cost. $^{253}$

There is a certain intuitive appeal to thinking of indices as news. Index outputs are information, like news, which can produce benefits from wide dissemination. Index providers have a journalistic character both in the manner that they acquire information and in their historical ties to news agencies. ${ }^{254}$

248. Standard \& Poor's Corp. v. Commodity Exchange, Inc., 538 F. Supp. 1063 (S.D.N.Y 1982) (Comex I), aff'd, 683 F.2d 704 (2d Cir. 1982) (Comex II).

249. Comex l, 538 F. Supp. at 1069.

250. Comex II, 683 F.2d at 711 .

251. 456 N.E.2d 84 (IIl. 1983)

252. 248 U.S. 215 (1918). See also U.S. Commodity Futures Trading Comm'n v. McGraw Hill Cos., 390 F. Supp. 2d 27 (D.D.C. 2005) (holding that Platts has a First Amendment "reporter's privilege" to its proprietary data and vetting techniques).

253. Id. at 245 (explaining that the injunction "restrains any taking or gainfully using of the complainant's news, either bodily or in substance, from bulletins issued by the complainant or any of its members, or from editions of their newspapers, "until its commercial value as news to the complainant and all of its members has passed away."').

254. For example, Dow Jones retains the Editor-in-Chief of the Wall Street Journal on the board of its index committee; FTSE's first two letters stand for Financial Times, its founder and erstwhile 50 percent owne
Still, INS is a poor foundation for the property rights of indices. First, the ase is no longer binding federal law, as it was based on federal common-law reasoning abandoned in Erie Railroad Co. v. Tompkins. ${ }^{255}$ Second, while INS remains influential under state law, recent Second Circuit decisions have dangerously narrowed its applicability, ruling that it is preempted by federal copyright law except in a narrow range of circumstances. ${ }^{256}$ The most important recent case to address INS is Barclays Capital Inc, $v$ Theflyonthewall.com $(F / y)$, in which the Second Circuit near-fatally narrowed he doctrinal basis for index rights as well as exposing the ill-conceived basis upon which index property protection had long rested. ${ }^{257}$

The defendant in Fly ("Fly") obtained research reports that financial firms like Barclays sent to customers, and then rapidly summarized the investment recommendations for Fly's own customers. Fly could provide the essence of he report and recommendations for a price that did not reflect the bank's production costs. The buy and sell recommendations of major investment banks tend to move markets, and the initial possessors of those reports can benefit if they can act on a recommendation before it becomes widely known. By publicizing the report to a broader base before the market opens, Fly deprived the banks' clients of that benefit. Among other things, this reduced the incentive for customers to maintain relationships with Barclays and pay commissions on trades. Put simply, Fly's business model was to free-ride on large banks' research.

Yet, the Second Circuit found no free-riding and ruled for Fly. Widely acknowledged as marking the death of INS ${ }^{258}$ Fly explicitly relegated the "hot news" multifactor test of National Basketball Association v. Motorola, Inc., INS"s progeny, to the realm of dicta. ${ }^{260}$ The court declared that "Fly is not, under $N B A$ 's analysis, "free-riding,", ${ }^{261}$ primarily because "[i]t is collecting, collating and disseminating factual information - the facts that Firms and

255. Bayial Inc. v. Theflyonthewall.com, Inc., 650 F.3d 876, 894 (2d Cir. 2011) 255. Barclays Capital Inc. v. Theflyonthewall.com, In Erie Railrood (Fly) (noting that INS represented fed

256. See Shyamkrishna Balganesh, "Hot News": The Enduring Myth of Property in News, 111 256. See Shyamkrishna Balganesh, Hot News CoLUM. L. REV. $419(2011)$. While generally critical of

257. 650 F.3d 876 (2d Cir. 2011).

258. See, e.g. Derek Bambauer, Flyonthewall Not Squashed, INFO/LAW (June 21, 2011), http://blogs.law.harvard.edu/infolaw/2011/06/21/flyonthewall-not-squashed ("The case smartly inters INS v. AP, the turgid Supreme Court case that generated the "hot news" misappropriation tort.") Camille Calman and Robert D. Balin, The Future of the Hot News Misappropriar (Sept. 16, 2011), Capital Inc.. Thertyon/2011/09/the-future-of-the-hot-news-misappropriation-tort-afterhttp://www.medialawmonitor.com/20l-com ("There seems little doubt that the hot news doctrine has suffered a serious blow in the Second Circuit."

259. $105 \mathrm{~F} .3 \mathrm{~d} 841$ (2d Cir. 1997) (NBA).

261. Id at 902 . 
others in the securities business have made recommendations . ..."262 The court treated the banks' recommendations exclusively as facts, and the intellectual property rights in facts are not readily awarded: "The Firms are making the news; Fly . . . is breaking it." ${ }^{3263}$ Of course INS had provided quasiintellectual property rights in facts, but the Fly court read INS protections very narrowly. For example, "hot news" protection requires direct competition, but the court found that the banks and Fly were not competitors. The plaintiffs offered brokerage services, whereas Fly reported on recommendations. The court was unconcerned that Fly marketed brokerage services to its customers that did compete with the banks, the economic equivalent of direct competition. ${ }^{264}$

Fly is clearly a problematic precedent for index rights. It diminishes the precedential power of INS, upon which index rights currently rest. It applies INS and its progeny so narrowly that there is little hope of an index provider taking shelter in it. For example, the direct-competition requirement would prevent a competitor from creating and licensing a copycat index identical to the S\&P 500 since both companies would then be in the index-licensing business. But it would not seem to prevent a competitor from using the S\&P 500 in derivatives or funds, which it then offered to the public, since product creation is a different line of business. Yet these unauthorized products would compete with the index provider's licensees, who might prefer to buy the copycat product rather than license the real thing. These are the exact facts of Comex I, and if Fly's direct competition requirement had been applied there, providers' property rights might never have been recognized.

Perhaps the most dangerous element of Fly is not what it changes from prior precedents, but what it explicitly maintains: INS protected hard work, not discretion or judgment. The Fly court did not find INS-type hard work, since "[i]n pressing a 'hot news' claim against Fly, the Firms seek only to protect their Recommendations, something they create using their expertise and experience rather than acquire through efforts akin to reporting." ${ }^{.265}$ Expertise, experience, reflection and judgment, the court held, were not "effort" akin to reporting, and therefore the plaintiffs did not invest the proper kind of work into producing their reports.

Fly thus illustrates the limits of the newsgathering analogy. The court's reasoning accurately reflects INS's 90 -year obsession with hard work in investigation rather than expertise in judgment. Every major decision concerning indices has cited INS and followed it in emphasizing investment of

$$
\begin{aligned}
& \text { 262. Id. } \\
& \text { 263. Id. } \\
& \text { 264. Id. at } 904 . \\
& 265 . \quad I d \text {. at } 903 .
\end{aligned}
$$

labor rather than creativity. ${ }^{266}$ But effort-based protections for indices become less plausible as the cost of indexing drops through scalable technology. Although S\&P spends a great deal to be in the index business, the marginal cost of an additional index has become quite low, and many of its inputs are public prices requiring little investigative effort. ${ }^{267}$ Many indices are produced as byproducts, so it is hard to attribute cost and effort directly to their production. Most importantly, the value of indices is about judgment and discretion in precisely the ways that courts from INS to Fly have excluded from hot news protection. The utility of an index's methodology, output value, and data stems not from the sweat that went into producing it, but from the well-exercised judgment of its provider.

\section{ii. Indices as Securities}

As the strained analogy to news weakens, taking index protections with it, another bad analogy has arisen that prevents the protection of index property claims in the first place. Courts seem to imagine that an index provider is like a firm that has gone public, and that index values, once licensed, are like ordinary securities. This baffling view has caused indices to lose key legal battles, and with them, providers' property rights.

Foremost among these cases is Dow Jones \& Co., Inc. v. International Securities Exchange, Inc. ${ }^{268}$ There, defendant ISE created, listed, and facilitated the trading of options on shares of an exchange traded fund ("ETF") that, in turn, tracked the Dow Jones Industrial Average. The dispute concerned whether unauthorized index derivatives trading amounted to misappropriation from the creator of the index. ${ }^{269}$ The plaintiff's claims would seem to be similar to those in $C B O T$ and Comex $I$ and therefore likely to prevail.

The court found for ISE and against the plaintiff on the ground that defendant had created options on an ETF and not on the index itself. The index provider may have a right to withhold its proprietary formulas from users, but "[b]y authorizing the creation of ETFs using their proprietary formulas, and the sale of the ETF shares to the public, the plaintiffs [] relinquished any right to control resale and public trading of those shares."270

266. See Standard \& Poor's Corp. v. Commodity Exch., Inc., 538 F. Supp. 1063 (S.D.N.Y. 1982); McGraw-Hill Cos., Inc. v. Int'l Sec. Exch., Inc., No. 05 Civ.1129(HB), 2005 WL 2100518 (S.D.N.Y. Sept. 1, 2005), aff d sub nom. Dow Jones \& Co., Inc. v. Int'I Sec. Exch., Inc., 451 F.3d 295 (2d Cir. 2006); see also Chicago Bd. of Options Exch., Inc. v. Int'I Sec. Exch., LLC, No. 06-CH-24798, at 14 (IIl. Cir. Ct. July 8, 2010) (citing INS's progeny as "the source from which Illinois misappropriation law arose.").

267. Telephone interview with Alex Matturri, CEO of S\&P Dow Jones Indices (Dec. 19, 2011) (asserting that anyone with a spreadsheet and a data stream can be in the index business).

268. 451 F.3d 295 (2d Cir. 2006)

269. Id. at 302 ("Plaintiffs have invested time, money, and intellectual creativity into the creation and maintenance of their indexes. Each argues that this gives it an intellectual-property right in index itser, as well as in an ETF that tracks the index, and in options on shares of such an ETF." 270. Id. at 303. 
The court posited that an option is merely a particular, conditional form of trading securities, and vendors or issuers lack the right to constrain the trading of securities once released. In so holding, the court followed Golden Nugget, Inc. v. American Stock Exchange, Inc., where an exchange-listed corporation sought to block the exchange from trading options on its stock. ${ }^{271}$ The Ninth Circuit declared that the trading of such options could not be constrained. ${ }^{272}$

The reasoning of Dow Jones allows anyone to circumvent the property rights recognized in Comex $I$ and CBOT. Dow Jones permits competitors to write an option whose value is determined by the value of shares of an S\&P 500 index fund. Such an option will have essentially identical payout as verboten options on the index itself. Since nearly all index providers license their index for use in some fund or derivative, and since courts see no reason to afford those securities any special treatment under law, the market has become free to create the economic equivalent of licensed index products without ever paying a licensing fee. ${ }^{273}$ Decisions like Dow Jones cast the future of product indices into disarray. ${ }^{274}$

\section{iii. Consequences of Declining Property Protetion}

The stakes are high for index providers who have a business model that depends upon charging market participants for use of their financial products. An index provider that is unable to control use of its index in derivatives cannot charge for such use. Unlike a company that will still issue shares, such an index has been denuded of significant revenue and may cease production. The implications of cases like Dow Jones are crucial for the financial viability of index production: "Since ETF options are among the most actively traded derivative contracts in the U.S., it is estimated that this result cost index licensors tens of millions of dollars in annual revenue.,275

The trend in recent case law has been to diminish index property rights, dangerously undermining the incentives for product index providers to produce future indices, manage extant indices well, and prevent index problems.

Already, product index providers are a diminishing pack. Concern for weakening property rights has led to a wave of mergers in the index

271. Golden Nugget, Inc. v. Am. Stock Exch., Inc., 828 F.2d 586 (9th Cir. 1987)

272. Id. at 591 .

273. See, e.g., Nasdaq Stock Mkt., Inc. v. Archipelago Holdings, LLC, 336 F. Supp. 2d 294 303-04 (S.D.N.Y. 2004) (rejecting Nasdaq's suit to prevent Archipelago from facilitating unauthorized tades of shares of a Nasdaq-affiliated ETF).

274. Dow Jones follows Fly's direct competition requirement in raising form over economic substance. Both disallow one transaction as misappropriation while allowing an economically equivalen

275. Neal Wolkoff, Changes At The Exchanges, J. INDEXES, Jan./Feb. 2007, http://www.indexuniverse.com/publications/journalofindexes/joi-articles/2630.html. Indexing is a global

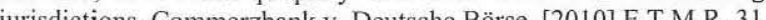

business. ${ }^{276}$ Exchanges may buy indices because they fear that product index providers may be unable to dependably provide indices if they cannot charge a license fee. Buying the provider will ensure an exchange access to the basis of its exchange-traded options. But such a merger ultimately represents a move from product to byproduct index. They therefore carry risks of malproduction and manipulation in the form of conflicts of interest and competition concerns, which are likelier for byproduct indices.

Some providers may adapt to weakened property rights by refusing to disclose aspects of their index that others might copy, keeping more and more products in-house. However, the tradeoff in information is rarely between intellectual property rights and a commons. ${ }^{277}$ Rather, firms will resort to secrecy if publicity dissipates the value of their information, even though secrecy is often socially wasteful. In the index world, this is partly expressed through fund managers campaigning to run their own indices. ${ }^{278}$ Secretive, inhouse indices may reduce market transparency and increase agency problems for investors. ${ }^{279}$ The creation of indices within funds also represents a migration from product to byproduct production as an index is taken in-house to serve fund purposes.

\section{Restoring Property}

Reversing the trend of eroding index property rights would slow adverse changes in the market, as well as provide a path for existing byproduct providers to adopt a product model. Allowing providers to directly internalize the benefits they create may help solve the implicit collective action problem of indices as public goods.

To provide some perspective, the global notional value indexed to Libor exceeds $\$ 350$ trillion. The vast majority of users do not pay any licensing fee to the BBA for the use of BBA Libor as a settlement price. If BBA were able to charge 3 basis points, or $0.03 \%$, of notional value as an annual fee to its present derivatives users, the result would be about $\$ 100$ billion in annual revenue. ${ }^{280}$ $\$ 100$ billion is a large sum of money, even in terms of global finance.

276. Telephone interview with Alex Matturri, Chief Executive Officer of S\&P Dow Jones Indices (Dec. 19, 2011).

277. Edmund M. Kitch, The Nature and Function of the Patent System, 20 J.L. \& ECON. 265, 275-80 (1977).

278. See supra notes $146-150$ and accompanying text.

279. Compefition and exclusivity of license are compatible. ETF fees are structured as a cost to the fund manager, and so we are less worried in this case about the failures of competition in the fund
industry. See generally Jon Morley \& Quinn Curtis, Taking Exit Rights Seriously. Why Governance and industry. See generally Jon Morley \& Quinn Curtis, Taking Exit Rights Seriously, Why Governance and limits of competition to constrain fees). 280. S\&P 500 licensees' funds pay more than 3 bps for the right to track the S\&P in their funds. 
Able to see the explicit value of the BBA Libor index, BBA and the pane banks might treat the index like a product. ${ }^{281}$ They would have adequate incentives to prevent indexing risks, investing in governance and systems to prevent employee manipulation. If the disturbances were reputational, the banks would have to weigh reputational effects against the damage to a valuable revenue stream. Even in the turmoil of a crisis, such revenue would not be risked lightly.

Stronger intellectual property amounts to promoting the growth of product indices and the migration of byproduct indices to a product model. For example, if Libor were more trustworthy and valuable as an independent entity from the bank's primary business, they might spin it off to an independent indexing firm with which they have a contract to share data.

Some amount of malproduction and underproduction can come from a product index provider's market power. ${ }^{282}$ However, their risks are often better managed than those of byproduct indices. Product indices are more responsive to market forces than are byproduct indices. Moreover, the licensing fees would be sufficiently attractive to encourage competitors, drawing more participants into the field. Although it is costly to transition loan and swap parties to a new index, a $\$ 100$ billion annual revenue stream could be large enough for a competitor to compensate users for the difficulty of overcoming lock-in. ${ }^{283}$

We are aware that our emphasis on property rights bucks the trend in intellectual property circles, which increasingly criticize propertization. ${ }^{284} \mathrm{~A}$ full treatment of the efficacy or normative defensibility of the U.S. intellectual property regime is beyond the scope of this Article. Suffice it to say that financial index providers have special reasons for property protection that largely sidesteps that debate. First, infamous holdup opportunities are not present here. It is unlikely that indices serve as crucial building blocks in any context except as components of the financial derivatives or funds based upon them. They are therefore unlikely to stack or inhibit innovation. ${ }^{285}$

Second, index providers are more sympathetic recipients of ongoing property protection because of indices' dependence upon their creators' continuing efforts. A company's logo, an artist's painting, and an inventor's

281. Presumably, BBA would share revenues with the panel banks it represents in order to support and encourage their honest submissions.

282. Propertization can also fail to account for "spillover" benefits to third parties. See generally BRETT M. Frischmann, INFRASTRUCTURE: THE SOCIAL VAlUE OF SHAREd RESOURCES (2012) (arguing that infrastructure resources should be managed as commons rather than privately

283. See supra Subsection II.D.1

284. See, e.g., Yochai Benkler, Freedom in the Commons: Towards a Political Economy of Information, 52 DUKE L.J. 1245 (2003) (urging commons production); Steven Shavell \& Tanguy van Y

285. See generally Mark A. Lemley \& Carl Shapiro, Patent Holdup and Royalty Stacking, 85 TEX. L. REV. 1991 (2007) (arguing that the U.S. intellectual property regime facilitates holdup
opportunities). invention each remains useful even if their creators abandon them. Because these extant goods can be expected to persist, intellectual property law may balance the competing interests of the present distribution of those goods against future production of new goods. ${ }^{286}$ By contrast, the value of a financial index requires continuing effort from its creator to update the methodology and apply it. If Standard \& Poor's exits the index business, the public does no simply lose out on future index innovation; existing indices will instantly disappear. The benefits of intellectual property for dynamic efficiency are usually opposed to reductions in static efficiency; by contrast, static efficiency often urges index prioritization too.

Third, we have already seen much of the result of this proposal, and it was unobjectionable. Though this proposal does urge a change of, and increase in, property rights in this space, it mostly urges a project of retrieval and doctrinal clarification. The index market functioned satisfactorily for decades. Recent legal changes have resulted in undesirable market trends, and so we urge undoing those changes. This is unlike other areas of intellectual property where increased propertization constitutes a novel change, and one associated with known problems.

Our present purpose is to urge greater propertization, not to define the contours of the optimal intellectual property regime for financial indices. ${ }^{287} \mathrm{It}$ must suffice to note some of the features of a proposed regime. First, index property rights must be secured with federal, not state, law. This is in part because of the mismatch in protections offered under state law, the focus on the "sweat of the brow," which fails to appreciate and protect the creativity of the indexing process. ${ }^{288}$ Further, if the erosion of state misappropriation doctrine were reversed, the resulting regime might protect far more than just financia indices, a result that this proposal cannot be taken to justify. Finally, interstate diversity in index property is inappropriate given the national character of indices and index use.

Within the federal regime, there is no perfect fit under existing options. Therefore, a sui generis treatment, akin to that of mask works ${ }^{289}$ and boat hulls ${ }^{290}$ may be appropriate. ${ }^{291}$ This is in part because indices have at least

286. Scholars have long described this tradeoff as between "dynamic" and "static" efficiency Compare Harold Demsetz, Information and Efficiency: Another Viewpoint, 12 J.L. \& ECON. 1, 14 (1969), with Kenneth J. Arrow, Economic Welfare and the Allocation of Resources for Invention, in THE RATE AND DIRECTION OF INVENTIVE ACTIVITY: ECONOMIC AND SOCIAL FACTORS 609, 623 (Nat') Get Beyond Irellectul Property Internalism, 59 UCLA L REV 970, 981-93 (2012) (deseribing the

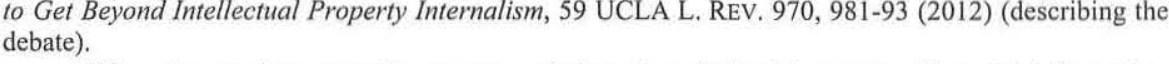

287. In ongoing research, we are exploring the relationships among financial information, financial indices, and intellectual property.

288. See supra Subsection III.B.1.i.
289. Semiconductor Chip Protection Act of 1984, Pub. L. No. 98-620, § 301, 98 Stat. 3347 (1984) (codified at 17 U.S.C. $\$ \$ 901-14$ ).

290. Vessel Hull Design Protection Act, Pub. L. 105-304, §§ 501-02, 112 Stat. 2860 (1998) (codified at 17 U.S.C. $\$ \$ 1301-32$ ) 
three protectable components. Federal trademark law protects the name of the index, but there is also an output value and an input methodology to protect. Federal copyright law attaches to creativity, and could have been applied to financial indices had courts not been influenced by the myth of objectivity. But even copyright law could protect only the output of the index, not its inputs.

The methodology for producing the index, which producers license to investment funds, would require non-copyright treatment. ${ }^{292}$ One option would be a business methods patent, although cases like Bilsky have curtailed the scope of patent protection for business methods. ${ }^{293}$ In any case, the limited duration of either copyright or patent implies that at some point the protection of the index will expire and copying will be permitted — but it is not obvious that index providers should ever surrender their property interest in the index they consistently maintain and innovate.

To be clear, our proposal does not urge property to the exclusion of other modes of production, such as government subsidy or peer-production. Those modes of production exist in the public and byproduct models, which demonstrate their own distinct risks and competencies. Our exploration of property is warranted because there is little reason to believe those models will always be superior to a product model, particularly when property is paired with appropriate limitations.

For instance, fair-use exceptions to property rights would protect many of the functions indices serve and from which it would be inefficient to exclude users. No one should have to pay to explain that their investment beat the S\&P 500 's returns. But it is unlikely that any index provider would attempt to prevent such uses of the index anyway; they benefit from the index's fame. ${ }^{294}$ For commercial users, it may be appropriate for the SEC to adopt a compulsory licensing regime that forbids exclusive dealings between a provider and a single product vendor. ${ }^{295}$ Steps like this can reduce the costs of property.

291. Sui generis regimes have been subject to criticism, e.g., David Nimmer, Codifying Copyright Comprehensibly, 51 UCLA L. REV. 1233,1327-1331 (2004), but may nevertheless be the best option given the concerns addressed.

292. The United States generally does not recognize copyrights in databases or compilations. See Feist Publ'ns, Inc. v. Rural Tel. Serv. Co., 499 U.S. 340 (1991). But see CCC Info. Servs. v. Maclean Hunter Mkt. Reports, Inc., 44 F.3d 61 (2d Cir. 1994) (recognizing copyright protection for (a) 293.

293. Bilski v. Kappos, 130 S. Ct. 3218 (2010)

294. Telephone interview with Alex Matturri, Chief Executive Officer of S\&P Dow Jones dices (Dec. 19, 2011)

295. S.E.C. Rule 19c-5, 17 C.F.R. $\$ 240.19 c-5$ (2012), prohibits an exchange from adopting rules that would bar the exchange from listing any stock options class "because that options class was from being a party to exclusive licensing arongements, the effect of which is to inhibit the listing of index options on other exchanges. See Chicago Bd of Options Exch. Inc. $v$. Int'l Sec. Exch. LLC, No. 06-CH-24798, at 14-15 (IIl. Cir. Ct. July 8, 2010). This parallel rule, would do much to addess output restrictions and market power.
The practical implementation of this proposal is more feasible because of last year's Dodd-Frank Act. ${ }^{296}$ Dodd-Frank requires the clearing at Derivatives Clearing Organizations of many derivatives that were once over-the-counter For the first time, swaps from all over the country will be centralized and subject to rules. It would be easy to collect licensing fees from the clearinghouse, which could pass the fees on to its users. At the very moment that product index economics are most necessary, it has become practically possible to collect fees from swap participants using indices like Libor.

\section{Conclusion}

This Article makes two novel contributions. First, we develop a taxonomy and model for understanding financial indices. This framework emphasizes the irreducible subjectivity built into index production. This subjectivity, which is a key component of indices' value to users, also carries the potential for manipulation and malproduction. Our model goes on to show that the risks inherent in indices are fundamentally related to their type, and any solutions must be tailored to an index's taxonomic characteristics. Recognizing that many index problems are rooted in a market failure of unstable or uncertain property rights, our second major contribution is developing a novel solution applicable to a whole range of index problems. Counterintuitively, the best way to prevent index manipulation may be through increasing present index providers' intellectual property protections.

296. Title VHI of the Dodd-Frank Wall Street Reform and Consumer Protection Act of 2012, 